\begin{abstract}
UNIVERSIDADE DE BRASÍLIA
FACULDADE DE CIÊNCIAS DA SAÚDE

PROGRAMA DE PÓS-GRADUAÇÃO EM CIÊNCIAS FARMACÊUTICAS
\end{abstract}

ANA CAROLINA ALVES ROCHA

COMPARAÇÃO ENTRE AS METODOLOGIAS ANALÍTICAS ELISA E QUIMIOLUMINESCENCIA PARA DOSAGEM DE ANTI-TRANSGLUTAMINASE IGA PARA DIAGNÓSTICO SOROLÓgICO DE DOENÇA CELÍACA

BRASÍLIA 


\section{COMPARAÇÃO ENTRE AS METODOLOGIAS ANALÍticas ELISA E QUIMIOLUMINESCÊNCIA PARA DOSAGEM DE ANTI-TRANSGLUTAMINASE IGA PARA DIAGNÓSTICO SOROLÓGICO DE DOENÇA CELÍACA}

Dissertação de Mestrado apresentada ao Programa de PósGraduação em Ciências Farmacêuticas da Faculdade de Ciências da Saúde, Universidade de Brasília, como requisito parcial à obtenção do título de Mestre em Ciências Farmacêuticas.

Orientadora: Profa. Dra. Yanna Karla de Medeiros Nóbrega

Brasília 
Ficha catalográfica elaborada automaticamente, com os dados fornecidos pelo (a) autor(a)

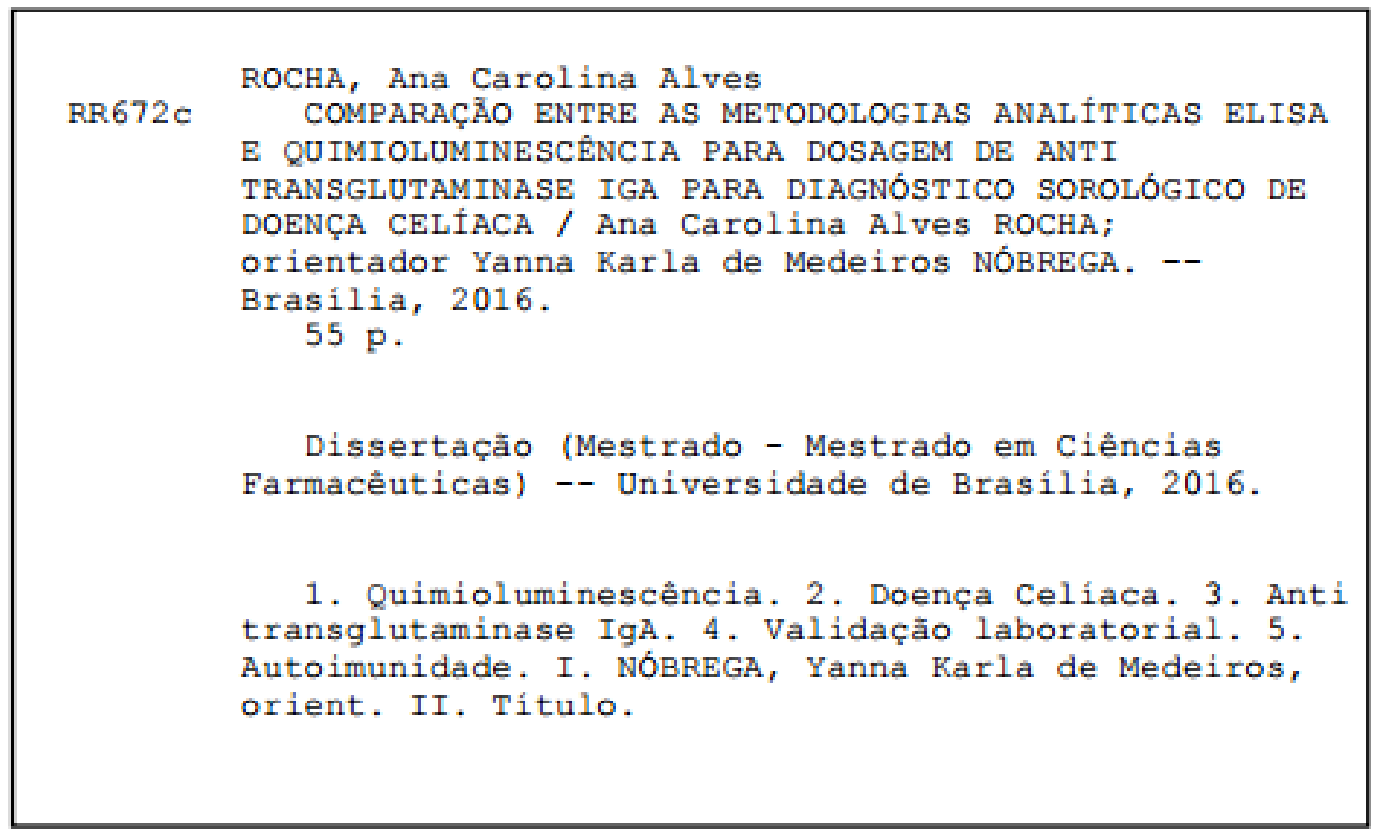


COMPARAÇÃO ENTRE AS METODOLOGIAS ANALÍTICAS ELISA E QUIMIOLUMINESCÊNCIA PARA DOSAGEM DE ANTI-TRANSGLUTAMINASE IGA PARA DIAGNÓSTICO SOROLÓGICO DE DOENÇA CELÍACA

Dissertação de Mestrado apresentada ao Programa de Pós-Graduação em Ciências Farmacêuticas da Faculdade de Ciências da Saúde, Universidade de Brasília, como requisito parcial à obtenção do título de Mestre em Ciências Farmacêuticas.

Aprovada em 09 de agosto de 2016

\section{Banca Examinadora}

Profa. Dra Yanna Karla de Medeiros Nóbrega - Universidade de Brasília

Prof. Dr. Pedro Sadi Monteiro- Universidade de Brasília

Prof. Dr. Maurício Homem de Mello - Universidade de Brasília

Profa. Dra Nadjar Nitz Silva Lociks de Araújo - Universidade de Brasília 
Este trabalho foi desenvolvido no Laboratório de Pesquisas em Doença Celíaca (LABDC), do Departamento de Patologia, da Faculdade de Medicina, da Universidade de Brasília (UnB). 


\section{AGRADECIMENTOS}

Agradeço à minha mãe, Cremilda Alves Moreira, pela força, exemplo de mãe, de garra e de dedicação. Agradeço a ela por ter me mostrado o amor de Deus por nós e a força e paz que Ele pode exercer em nossas vidas, principalmente nos momentos mais terríveis. Mamãe, obrigada pelo amor incondicional e pelo carinho nos momentos de dor.

Ao meu filho amado, Gabriel Rocha Freitas, que me faz acreditar que posso ser cada vez melhor. Agradeço a ele o meu amor, meu carinho, minha razão de chegar onde quero, pelas lindas palavras que ele me declara diariamente, pela nossa união e cumplicidade e por me mostrar o quanto sou importante na vida dele. Obrigada, meu anjinho, você é minha vida.

Às minhas lindas irmãs e amigas, Carla Camila e Isabela, que em muitos momentos me tornei caçula no colo delas. Agradeço-as pelo amor, carinho e preocupação que sempre despejaram em mim, especialmente nos momentos difíceis. Amo-as!

Ao meu namorado, Marcello Roza, que desde o início me incentivou a fazer o mestrado, me fez acreditar que eu seria capaz dessa conquista e de muito mais, por ser meu amigo em todos os momentos e nunca desistir de mim, do nosso amor e cumplicidade.

À minha querida orientadora, Yanna Nóbrega, que além de me ensinar como ser pesquisadora com seu exemplo, mostrou-se amiga, conselheira e incentivadora. Obrigada, Yanna, jamais esquecerei de tudo que aprendi com você e muito obrigada por nunca ter desistido de mim. Serei eternamente grata!

Ao professor Pratesi, que com seu carinho e incentivo, sempre me acolheu no laboratório para contribuir com as pesquisas. Meu desejo é poder contribuir cada vez mais.

À minha amiga e mãe do melhor amigo do meu filho, Mariana Salgueiro, que sempre se dispôs a me ajudar para eu conciliar trabalho e estudos, sem deixar que Gabriel sentisse muito a minha ausência. Serei eternamente grata pelo seu carinho com ele.

Aos colegas do laboratório, Cida, Lais, Nicole, Rosa, Fábio, Cristina, Adriana, Cristina e Zita, que sempre se dispuseram a me ajudar, seja nos equipamentos, nas buscas de amostras, até mesmo com outros materiais, vocês todos foram de grande importância para a conclusão desse trabalho.

À minha vovó querida e amada, Dona Divina, pelo exemplo de amor, carinho, mulher, sabedoria e inteligência. Por sempre ser minha amiga e dar os melhores conselhos.

Ao meu chefe, Paulo Martins, pelas inúmeras vezes que me ajudou no trabalho, pela compreensão e apoio que sempre depositou em mim. Aos meus colegas plantonistas noturnos do Hospital Materno Infantil de Brasília, Luciana, Cristina, Andreza, Daniel, Romildo, Zilda, Nonato, Marcão, Rogerinho, Edson, Cléia, Aralice, Camila, Pedro e Wislon, que tiveram que me aturar enquanto eu dividia meus estudos e meu trabalho. 


\section{RESUMO}

ROCHA, Ana Carolina Alves. COMPARAÇÃO ENTRE AS METODOLOGIAS ANALÍTICAS ELISA E QUIMIOLUMINESCÊNCIA PARA DOSAGEM DE ANTITRANSGLUTAMINASE IGA PARA DIAGNÓSTICO SOROLÓGICO DE DOENÇA CELÍACABrasília, 2016. Dissertação (Mestrado em Ciências Farmacêuticas) - Faculdade de Ciências da Saúde, Universidade de Brasília, Brasília, 2016.

A doença celíaca (DC) é uma desordem sistêmica e imunomediada por glúten em indivíduos geneticamente suscetíveis. A doença está associada ao antígeno leucocitário humano (HLA II), DQ2 e DQ8 e é caracterizada por inflamação intestinal, atrofia das vilosidades e autoimunidade. Os anticorpos IgA contra transglutaminase tecidual (tTG IgA) são marcadores sensíveis empregados no diagnóstico laboratorial da DC. Atualmente, existem duas metodologias laboratoriais mais empregadas na mensuração desse anticorpo, uma delas é a metodologia de ELISA, que é considerada método referência, e amplamente utilizada no diagnóstico de DC, e a outra, é a metodologia de quimioluminescência, cuja performance analítica foi objeto deste estudo. Foram analisadas 182 amostras de soro de pacientes do Laboratório de Pesquisas em Doença Celíaca (LABDC), 11 amostras positivas e 171 amostras negativas dosadas por Enzyme Linked Immuno Sorbent Assay - ELISA (método referência). Todas as amostras foram mensuradas empregando ELISA e quimioluminescência, nos equipamentos Best-2000® e Bio-Flash. Os resultados revelaram que a quimioluminescência comparada ao ELISA, é substancialmente concordante $(\mathrm{k}=0,732)$ e reprodutível, apresentando CV de controles negativos e positivos respectivamente de $4,4 \%$ e $3,4 \%$ na avaliação da precisão intraensaio, e na precisão interensaio, demonstrando $\mathrm{CV}$ para controles negativos de $2,9 \%$ e positivos de $2,7 \%$. O método apresentou sensibilidade de $81,8 \%$, especificidade de $97,6 \%$, e acurácia de 94\%, mostrando-se mais sensível que específico quando comparado ao método referência. No que se refere ao desempenho clínico-laboratorial da quimioluminescência, o método demonstrou Valor Preditivo Positivo (VPP) de 69,2\% e Valor Preditivo Negativo (VPN) de 98,8\%, que demonstra elevada capacidade de discriminar indivíduos celíacos e não-celíacos, por meio da curva ROC, que apresentou área sobre a curva de 0,9972. Diante das análises realizadas, podemos concluir que a metodologia de quimioluminescência além da sua robustez e randomicidade, apresentou cut-off semelhante ao método referência, capacidade discriminatória entre celíacos e não-celíacos, com Risco Relativo de 58,5 vezes maior para o desenvolvimento de DC quando tTG IgA for positivo, e Odds Ratio de 187,9 demonstrando forte associação entre o exame positivo e chance de desenvolver DC. Com estes resultados, podemos inferir que a quimioluminescência pode ser utilizada como método de escolha para o diagnóstico laboratorial da DC.

Palavras-chave: quimioluminescência, anti-transglutaminase $\operatorname{IgA}$, doença celíaca, diagnóstico laboratorial, imunoensaio, autoimunidade. 


\begin{abstract}
ROCHA, Ana Carolina Alves. LABORATORY COMPARISON ON ANALYTICAL METHODOLOGIES FOR ANTI- transglutaminase IGA DETERMINATION USED IN CELIAC DISEASE SEROLOGICAL DIAGNOSIS. Brasilia, 2016. Dissertation (Master in Pharmaceutical Sciences) - Faculty of Health Sciences, University of Brasília, Brasília, 2016.
\end{abstract}

Celiac disease (CD) is a systemic immune-mediated and gluten disorder in genetically susceptible individuals. The disease is associated with human leukocyte antigen (HLA II) DQ2 and DQ8 and is characterized by intestinal inflammation, atrophy of the villi and autoimmunity. IgA antibodies against tissue transglutaminase (tTG IgA) are sensitive markers used in laboratory diagnosis of $\mathrm{CD}$. Currently, there are two most used laboratory methods to measure the antibody, one of them is the ELISA methodology, which is considered the gold standard and widely used in the diagnosis of $\mathrm{CD}$ and the other, is the chemiluminescence method, whose analytical performance was studied in this research. Serum samples of 182 Research Laboratory patients in Celiac Disease (LABDC), 11 positive samples assayed by Enzyme Linked Immuno Sorbent Assay - ELISA (gold standard) and 171 negative samples. All samples were measured using ELISA and chemiluminescent Best-2000® and Bio-Flash devices. The results revealed that the chemiluminescence compared to ELISA is substantially consistent $(\mathrm{k}=0.732)$, and reproducible, with $\mathrm{CV}$ negative and positive controls respectively $4.4 \%$ and $3.4 \%$ in the assessment of intra-assay precision, and inter-assay precision negative controls showing CV $2.9 \%$ positive and $2.7 \%$. The method showed a sensitivity of $81.8 \%$, specificity $97.6 \%$ and accuracy of $94 \%$, being more sensitive than specific when compared to the gold standard. In regards to the clinical and laboratory performance, chemiluminescence method showed Positive Predictive Value (PPV) of 69.2\% and Negative Predictive Value (NPV) $98.8 \%$, which demonstrates high ability to discriminate celiac individuals and nonceliac, through the ROC curve, which showed an area of 0.9972 of the curve. On the analysis performed, we conclude that the chemiluminescence methodology beyond its robustness and randomness, presented cut-off similar to the gold standard, discriminatory power among celiacs and non-celiacs, with relative risk 58.5 times for development CD when TTG IgA is positive, and odds ratio of 187.9 demonstrating strong association between positive test and a chance of developing $\mathrm{CD}$. With these results, we can infer that chemiluminescence can be used as a method of choice for laboratory diagnosis of CD.

Keywords: chemiluminescence, anti- transglutaminase $\operatorname{IgA}$, celiac disease, laboratory diagnostics, immunoassay, autoimmunity. 


\section{LISTA DE FIGURAS}

Figura 1 - Representação da patogênese da DC....................................................... 3

Figura 2 - Critérios diagnósticos para DC......................................................... 5

Figura 3 - Parâmetros de validação do ensaio............................................................ 14

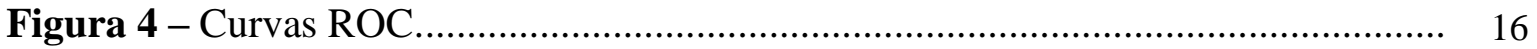

Figura 5 - Ilustração da metodologia de ELISA indireto para análise de anti-tTG IgA. 21

Figura 6 - Esquema de ensaio simplificado do procedimento realizado automaticamente pela quimioluminescência............................................................... 22

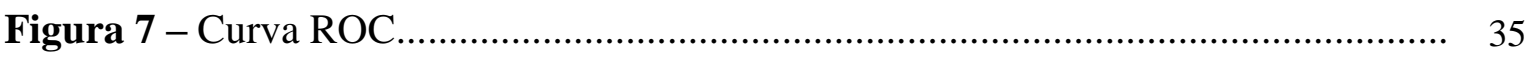




\section{LISTA DE TABELAS}

Tabela 1 - Valores esperados para os controles, fornecidos pelo fabricante..................... 27

Tabela 2 - Resultados de precisão intraensaio............................................................ 33

Tabela 3 - Resultados de controle negativo, precisão interensaio.................................... 34

Tabela 4 - Resultados de controle positivo, precisão interensaio...................................... 34

Tabela 5 - Parâmetros intrínsecos calculados para a metodologia de quimioluminescência tendo a metodologia de ELISA como método referência............................................. 37

Tabela 6 - Parâmetros que dependem da prevalência da doença calculados para a metodologia de quimioluminescência tendo a metodologia de ELISA como método referência. 


\section{LISTA DE QUADROS}

Quadro 1 - Vantagens da metodologia quimioluminescente frente a metodologia de ELISA

Quadro 2 - Combinação binária (matriz de contingência 2x2) entre o método referência (ELISA) e o método em validação (quimioluminescência).

Quadro 3 - Combinação binária (matriz de contingência $2 \times 2$ ) entre o método referência (ELISA) e o método em validação (quimioluminescência)...... 


\section{LISTA DE ABREVIATURAS E SIGLAS}

AGA: Anti-gliadina

APC: $\quad$ Antigen Presenting Cells

CU: $\quad$ Chemioluminescense Unit

CV: $\quad$ Coeficiente de variação

DC: Doença celíaca

DGP: Gliadina desamidada

DLG: $\quad$ Dieta livre de glúten

DO: $\quad$ Densidade Ótica

DP: Desvio-padrão

DSG: Dieta sem glúten

ELISA: $\quad$ Enzyme Linked ImmunoSorbent Assay

EMA: Anti-endomísio

ESPGHAN: European Society of Pediatric Gastroenterology, Hepatology and Nutrition

FN: $\quad$ Falso negativo

FP: $\quad$ Falso positivo

HLA: Human Leucocyte Antigen

IgA: Imunoglobulina A

IgG: $\quad$ Imunoglobulina $\mathrm{G}$

LABDC: Laboratório de Pesquisas em Doença Celíaca

LabIBC: $\quad$ Laboratório Interdisciplinar de Biociências

MHC: $\quad$ Major Histocompatibility Complex

OD: $\quad$ Odds ratio

PBS: $\quad$ Phosfate Buffer Solution

RLU: $\quad$ Relative Ligth Unit

ROC: $\quad$ Receiver Operating Characteristic

RR: $\quad$ Risco relativo

RV: $\quad$ Razão de verossimilhança

RVN: Razão de verossimilhança negativo

RVP: Razão de verossimilhança positiva

TMB: Tetrametilbenzina

tTG: $\quad$ Tranglutaminase 


$\begin{array}{ll}\text { U: } & \text { Unidades } \\ \text { UA: } & \text { Unidade Arbitrária } \\ \text { UI: } & \text { Unidades Internacionais } \\ \text { VN: } & \text { Verdadeiro Negativo } \\ \text { VP: } & \text { Verdadeiro Positivo } \\ \text { VPN: } & \text { Valor Preditivo Negativo } \\ \text { VPP: } & \text { Valor Preditivo Positivo }\end{array}$




\section{SUMÁRIO}

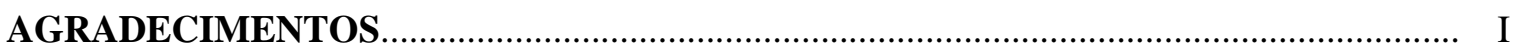

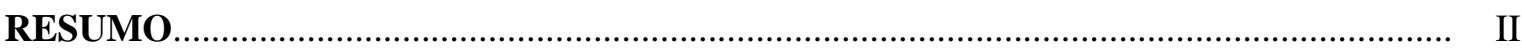

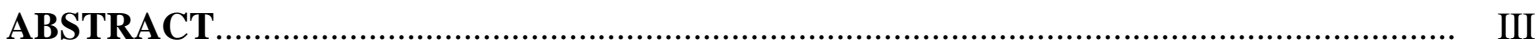

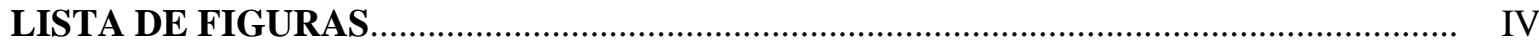

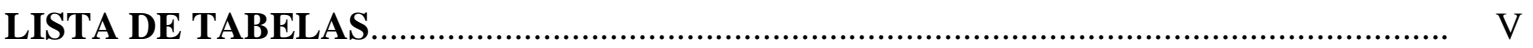

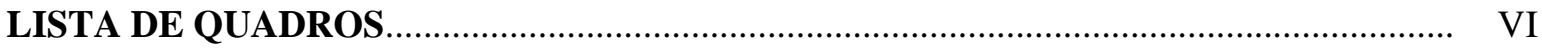

LISTA DE ABREVIATURAS E SIGLAS..................................................................... VII

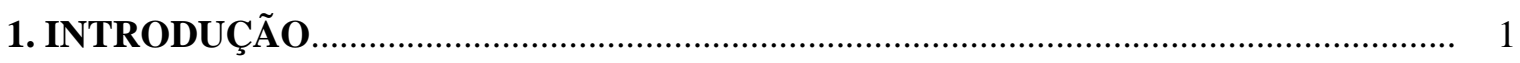

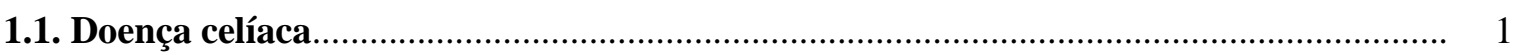

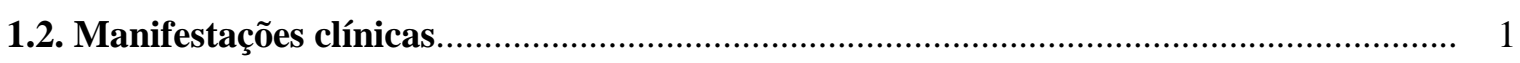

1.3. Patogênese

1.4. Sensibilidade ao gluten em indivíduos não celíacos........................................................ 3

1.5. Evolução do diagnóstico de doença celíaca......................................................................... 4

1.6. Diagnóstico laboratorial da DC.............................................................................. 5

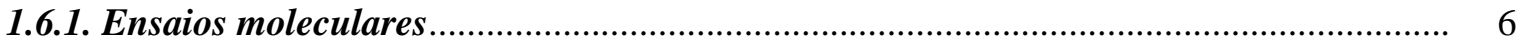

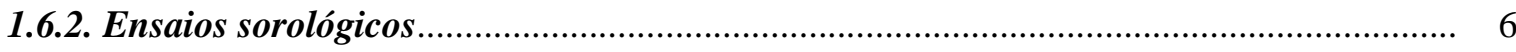

1.6.2.1. Anti-transglutaminase (anti-tTG) IgA..................................................................... 8

1.6.2.2. Anticorpos anti-gliadina (anti-AGA)........................................................................... 9

1.6.2.3. Anticorpos anti-endomísio (anti-EMA)...................................................................... 9

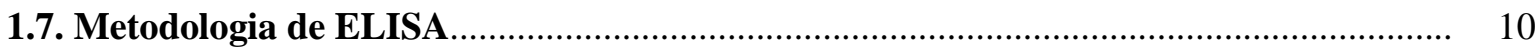

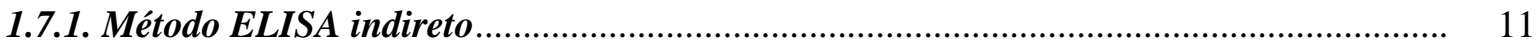

1.8. Metodologia de quimioluminescência.......................................................................... 11

1.9. Metodologias sorológicas para mensurar anti-transglutaminase IgA na detecção de

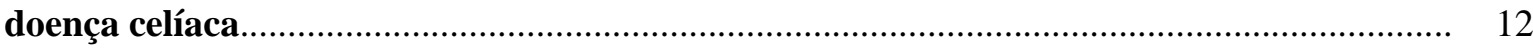

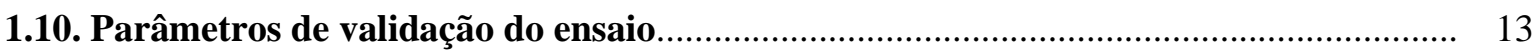

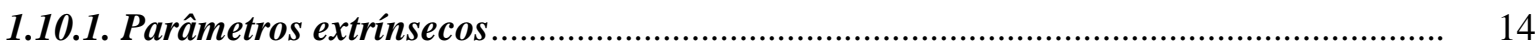

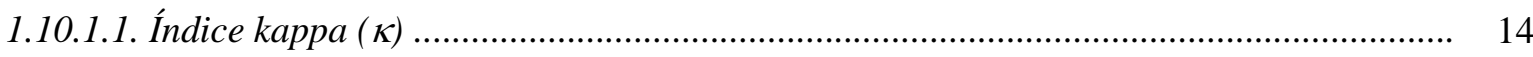

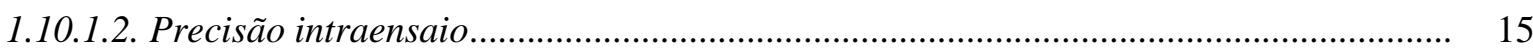

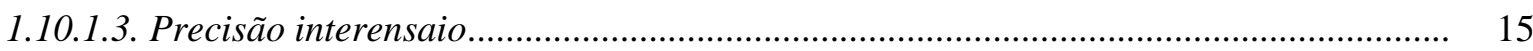

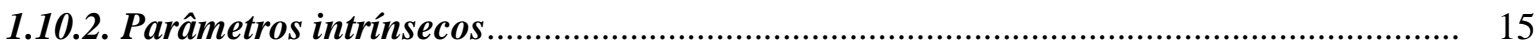

1.10.2.1. Curve Receiver Operating Characteristic (Curva ROC)............................................ 15

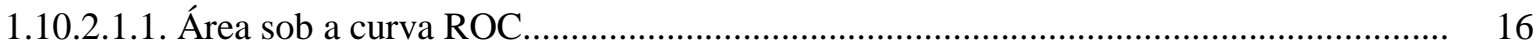

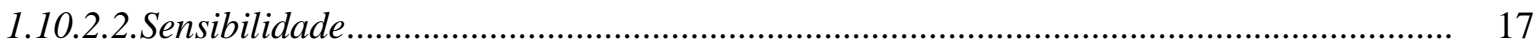


1.10.2.3. Especificidade

1.10.2.4. Eficiência ou acurácia......................................................................................... 17

1.10.3. Parâmetros que dependem da prevalência da doença .................................................... 17

1.10.3.1.Valor preditivo de um resultado positivo (VPP)......................................................... 17

1.10.3.2. Valor preditivo de um resultado negativo $(V P N)$......................................................... 18

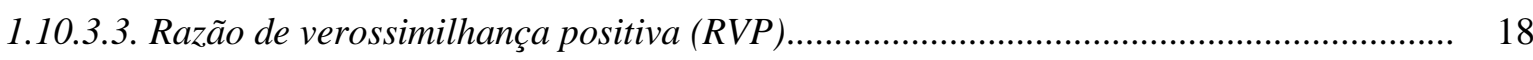

1.10.3.4. Razão de verossimilhança negativa $(R V N)$.................................................................. 18

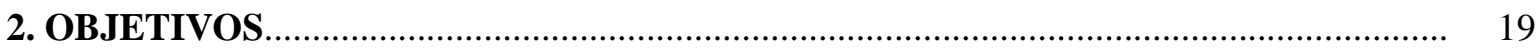

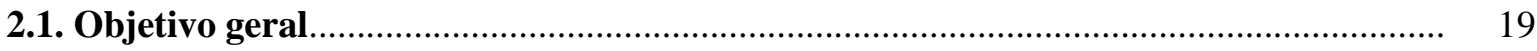

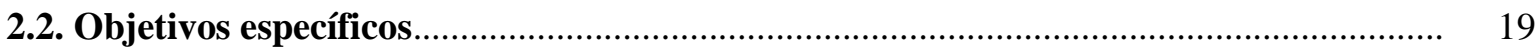

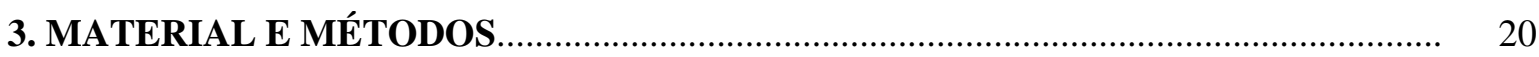

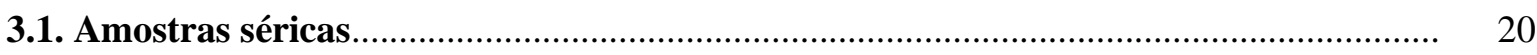

3.2. Anti-tansglutaminase IgA por ELISA indireto......................................................... 20

3.3. Anti-transglutaminase IgA por quimioluminescência................................................. 22

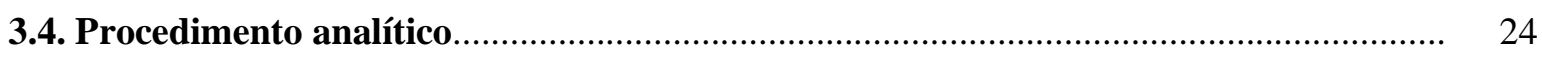

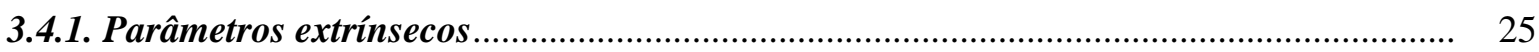

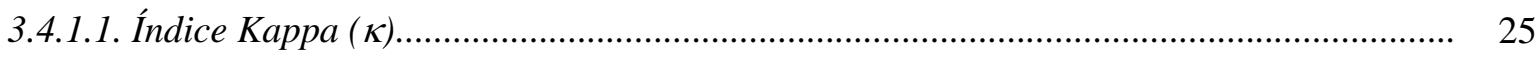

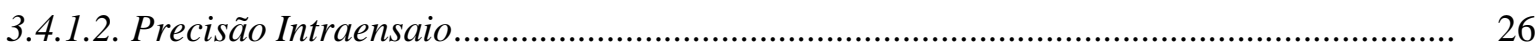

3.4.1.3. Precisão Interensaio............................................................................................ 27

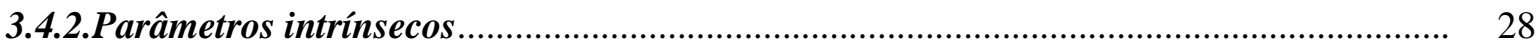

3.4.2.1. Curve Receiver Operating Characteristic (Curva ROC)............................................. 28

3.4.2.2. Sensibilidade .................................................................................................. 28

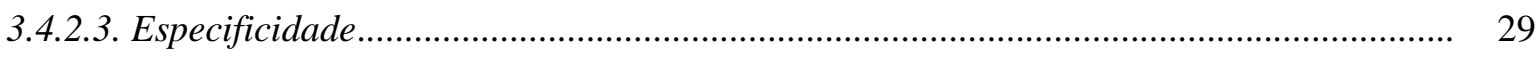

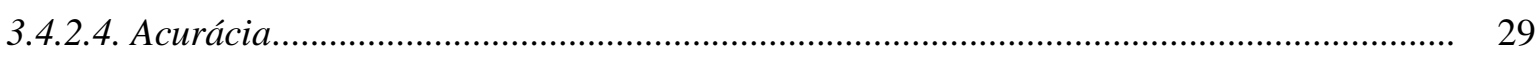

3.4.3. Parâmetros que dependem da prevalência da doença .................................................... 29

3.4.3.1.Valor preditivo positivo (VPP) ....................................................................................... 30

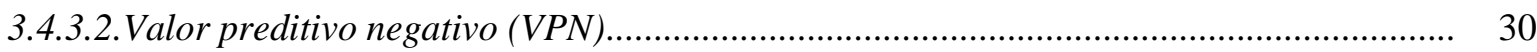

3.4.3.3.Razão de verossimilhança positiva $(R V P)$.................................................................. 30

3.4.3.3.Razão de verossimilhança negativa $($ RVN).................................................................. 30

3.5. Análise estatística....................................................................................................... 31

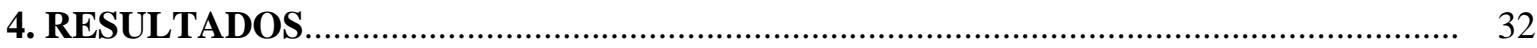

4.1. Parâmetros extrínsecos.......................................................................................... 32

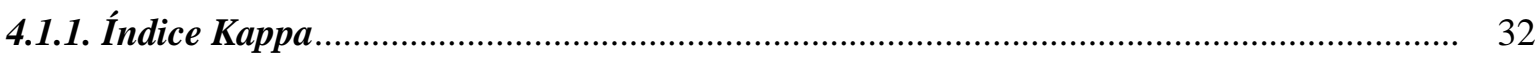

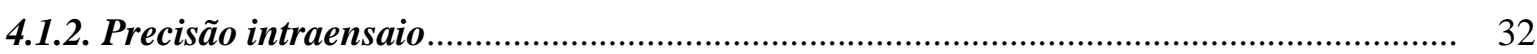

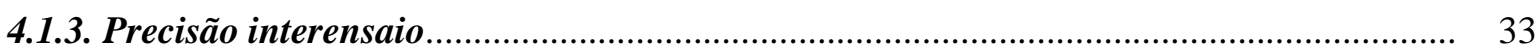

4.2. Parâmetros intrínsecos e parâmetros que dependem da prevalência da doença............. 35 
4.2.1.1. Curve Receiver Operating Characteristic (Curva ROC)............................................. 35

4.2.1.2. Sensibilidade, Especificidade e Acurácia ........................................................................ 35

4.2.2. Parâmetros que dependem da prevalência da doença ................................................... 37

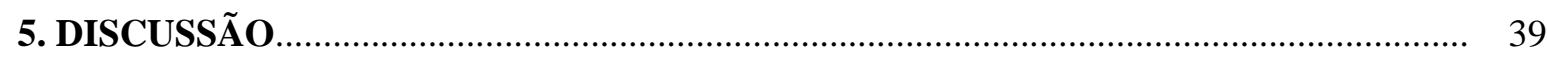

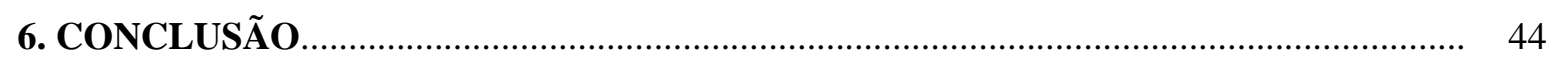

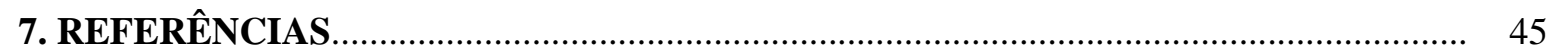

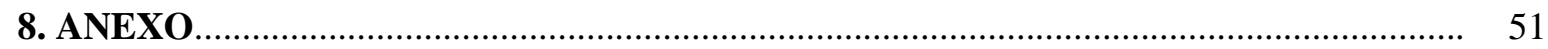




\section{INTRODUÇÃO}

\subsection{Doença celíaca}

A doença celíaca (DC) é uma desordem sistêmica e imunomediada por glúten em indivíduos geneticamente suscetíveis (HUSBY et al., 2012). A doença está associada com o antígeno leucocitário humano (HLA) classe II, DQ2 e DQ8 e é caracterizada por inflamação intestinal, atrofia das vilosidades e autoimunidade. Os anticorpos que estão diretamente envolvidos na resposta autoimune da DC são anticorpos do tipo IgA contra transglutaminase tecidual ou anti-transglutaminase (tTG), anti-endomísio (EMA) e anticorpos anti-gliadina (DGP) (CAJA et al., 2011; HUSBY e MURRAY, 2013).

A DC é uma condição permanente de intolerância ao glúten, onde a inflamação da mucosa intestinal pode ser reversível pela utilização de dietas livres de glúten (DLG) e a reintrodução do glúten na dieta, ocasiona a recidiva do quadro inflamatório da mucosa intestinal (LUDVIGSSON et al., 2013).

\subsection{Manifestações clínicas}

As manifestações clínicas da DC podem apresentar-se de várias formas, podendo confundir-se com outras desordens do trato gastrointestinal (LIONETTI e CATASSI, 2011). É de extrema importância diagnosticar não apenas crianças com quadro clínico clássico gastrointestinal, mas também aquelas que possuam sintomas leves ou ausentes, pois a doença pode trazer consequências negativas para a saúde (HUSBY et al., 2012).

Tradicionalmente pacientes com DC apresentam má absorção intestinal caracterizada por diarreia, esteatorreia, perda ou dificuldade em ganhar peso ou diminuição no crescimento (DC clássica). Pode ocorrer também manifestações clínicas extra intestinais (DC não clássica) ou ausência de sintomas (DC assintomática) (KELLY et al., 2015).

De acordo com as manifestações clínicas a doença celíaca pode ser classificada em (LIONETTI e CATASSI, 2011): DC clássica: quando apresenta diarreia crônica, retardo no crescimento, distensão abdominal, perda de massa muscular, anorexia e alterações comportamentais; $D C$ atípica: com anemia por deficiência de ferro, vitamina B12 e ácido fólico, baixa estatura, osteopenia e/ou osteoporose, aumento nas transaminases, dermatite hipetiforme, hipoplasia do esmalte dental, estomatite, dor abdominal, vômitos, constipação, 
dor de cabeça, polineuropatia, lesão de substância branca, ataxia cerebelar, epilepsia, atraso puberal, abortos, infertilidade; associada a doenças autoimunes: diabetes tipo I, tireoidite autoimune, hepatite autoimune, miastenia grave, cirrose biliar primária, colangite esclerosante primária, psoríase, Síndrome de Sjögren. E associada a doenças genéticas: síndrome de Down, síndrome de Turner, síndrome de Williams, deficiência IgA.

Todas essas formas clínicas e a diversidade de suas manifestações na DC enfatizam a necessidade de critérios de diagnóstico robustos (LUDVIGSSON et al., 2014).

\subsection{Patogênese}

O desenvolvimento da DC é determinado tanto por fatores ambientais quanto genéticos e influenciado pelos aspectos imunológicos. Em situações fisiológicas normais, o epitélio intestinal é impermeável a macromoléculas. Na DC, essa permeabilidade intercelular é comprometida, permitindo a passagem de macromoléculas como o glúten e seus componentes, nas estreitas junções celulares do epitélio intestinal (LIONETTI e CATASSI, 2011).

O glúten contém gliadina e glutenina, que são resistentes às enzimas proteolíticas gastrointestinais e não sofrem a hidrólise necessária para sua digestão completa e dessa maneira são disponibilizadas na lâmina própria do intestino (LINDFORS et al., 2011). A presença desses peptídeos de gliadina (imunógenos), em pessoas geneticamente predispostas, desencadeia uma resposta imunitária que entre outras ações, compromete a permeabilidade epitelial intestinal, uma das características da doença celíaca (CAJA et al., 2011).

Os peptídeos de gliadina que chegam à lâmina própria, decorrente da digestão incompleta do glúten, são desamidados pela enzima transglutaminase tecidual (tTG) (LINDFORS et al., 2011). A presença de gliadina inicia o processo de patogênese da doença celíaca, induzindo a secreção da enzima tTG (DIETERICH et al., 1997).

Pacientes celíacos expostos ao glúten, expressam altos níveis de anticorpos contra a gliadina, endomísio e contra a enzima transglutaminase tecidual (DIETERICH et al., 1997). A eliminação do glúten na dieta, diminui a presença significativa desses anticorpos desaparecendo as manifestações clínicas provenientes dessa resposta imune (DIETERICH et al., 1997; LINDFORS et al., 2011)

A resposta imune ao glúten é iniciada pelas Células Apresentadores de Antígeno (Antigen Presenting Cells - APCs) aos linfócitos T CD4+. As APCs expressam em sua 
superfície proteínas do Complexo de Histocompatibilidade Principal (Major Histocompatibility Complex - MHC) que se ligam aos peptídeos do glúten. Essas proteínas do complexo MHC presentes nas APCs são codificadas pelos genes HLA (Human Leukocyte Antigen) (LIONETTI e CATASSI, 2011). A suscetibilidade genética para DC, como demonstra a Figura 1, está associada aos heterodímeros HLA-DQ2 e HLA-DQ8 que estão envolvidos na patogênese (ABADIE et al., 2011).

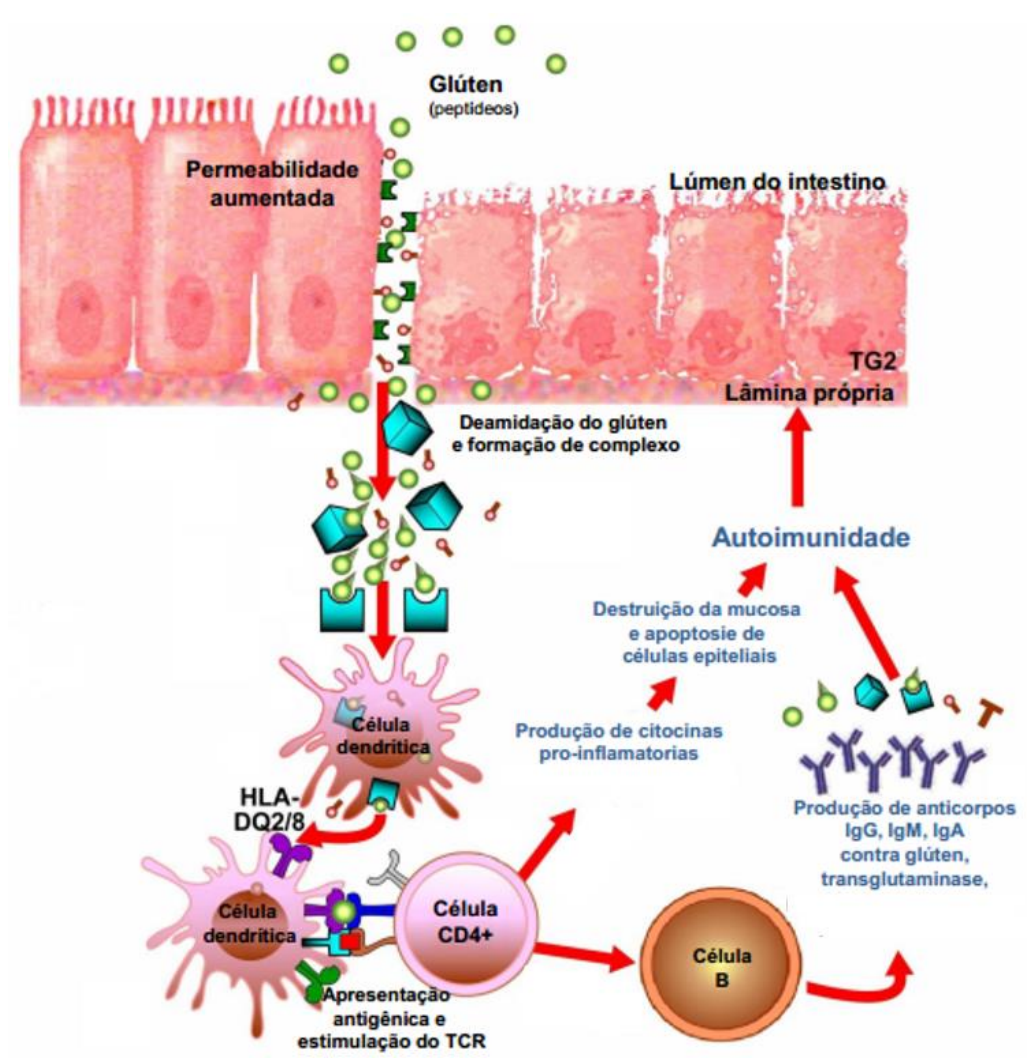

Figura 1 - Representação da patogênese da DC. Partes do gluten resistentes ao processo de hidrólise, atravessam a membrana epitelial do intestino delgado e sofrem a desamidação pela transglutaminase tecidual, formando o complexo gliadina desamidada e transglutaminase. As células T CD4+ reconhecem esse complexo por moléculas de superfície das APCs, expressas por HLA-DQ2 e/ou HLA-DQ8. Após esse reconhecimento, as células T CD4+ emitem dois sinais de resposta imune, um secretando citocinas pró inflamatórias, provocando a destruição e aumento na permeabilidade da mucosa intestinal, o outro, produzindo anticorpos contra a gliadina desamidada e contra a transglutaminase tecididual, sendo essa última a caracterização de autoimunidade. Diagrama adaptado de http://www.glutensensitivity.net/Celiac_Disease_with_text_050207.pdf acessado em 17 de agosto de 2016

\subsection{Sensibilidade ao glúten em indivíduos não celíacos}

Algumas pessoas podem apresentar manifestações sintomáticas após ingestão de glúten e ao investigar, a DC é descartada (LUDVIGSSON, et al, 2013). Ao contrário da DC, pessoas não celíacas com sensibilidade ao glúten podem mostrar sinais de resposta imune, 
porém, sem enteropatia, valores negativos para autoanticorpos contra tTG, EMA e DGP. (SAPONE et al., 2011). Estudo realizado por Hollon e colaboradores (2015), concluiu que a gliadina presente no glúten, provoca aumento na permeabilidade intestinal em todos os indivíduos estudados, independentemente de portarem a doença celíaca, mas a presença de anticorpos só ocorre nos celíacos.

\subsection{Evolução do diagnóstico da doença celíaca}

A primeira descrição da DC foi encontrada nos escritos do médico grego Aretaeus entre os anos 1 e 2 a.C. Ela foi descrita como uma doença intestinal associada a diarreia e má absorção com ocorrência em adultos e crianças, mais frequente em mulheres do que em homens (ABADIE et al., 2011). Gee, em 1888 relatou que a doença era ligada à alimentos e concluiu que a cura deveria começar pela dieta (DOWD e WALKER-SMITH, 1974).

Em 1950, Dicke e colaboradores, confirmaram que a remoção de alimentos provenientes de grãos de centeio e trigo resultaram em melhora significativa dessa condição (DICKE et al., 1953). Paulley em 1954, reportou o primeiro caso de manifestação clínica envolvendo a destruição do intestino delgado pela DC (PAULLEY, 1954).

A identificação dos anticorpos de gliadina, ocorreu em 1961, surgindo o primeiro teste sorológico não invasivo da DC (TAYLOR et al., 1961). Em 1992, Marsh estabeleceu a primeira classificação histológica das lesões provocadas pela DC, desde hiperproliferação das criptas intestinais com linfócitos intraepiteliais até total atrofia das vilosidades. Oberhuber e colaboradores (1999), modificaram alguns parâmetros e passou-se a utilizar a classificação Marsh-Oberhuber, a qual descreve cinco estados de injúria do intestino delgado (tipos de 0 a 4). Essa classificação é muito utilizada por patologistas, porém, existem algumas subjetividades ao classificar o tipo de lesão observada na biopsia.

Em 2012, Corazza e Villanicci dividiram as lesões da mucosa intestinal em duas grandes categorias. A primeira, é lesão sem atrofia das vilosidades com infiltrados de linfócitos, que são as lesões de grau A. A segunda categoria, grau B, representa as lesões com atrofia das vilosidades e infiltrados de linfócitos e é subdividida em B1 (aumento dos linfócitos intraepiteliais e hiperplasia de cripta) e em B2 (lesões mais graves, atrofia total das vilosidades (BAO, GREEN \& BHAGAT, 2012).

A Sociedade Europeia de Gastroenterologia, Hepatologia e Nutrição Pediátrica (European Society of Pediatric Gastroenterology, Hepatology and Nutrition -ESPGHAN) em 
1997, recomendava uma série de três biópsias, uma na manifestação da doença, outra na dieta livre de glúten e outra quando o indivíduo era novamente desafiado a consumir glúten para confirmar o diagnóstico. No entanto, essa abordagem era muito complicada e acabou sendo substituída por uma abordagem menos invasiva, exigindo apenas uma biópsia e o acompanhamento da resposta clínica com a dieta livre de glúten (HUSBY, 2012).

Avanços nos testes sorológicos e análises genéticas sugeriram uma outra abordagem, onde a biópsia nem sempre é necessária (MURCH, 2016). Em 2012, a ESPGHAN (Figura 2) revisou seus critérios diagnósticos e afirmou que em crianças pode ser diagnosticada sem biópsia em circunstâncias específicas, como sintomas evidentes e valores de antitransglutaminase (anti-tTG) acima do cut-off do kit diagnóstico utilizado em cerca de dez vezes o valor do limite de normalidade, além disso o anti-endomísio IgA deve apresentar-se positivo, e a confirmação da presença dos genes HLA-DQ2 ou HLA-DQ8 deve ser realizada (HUSBY, 2012).

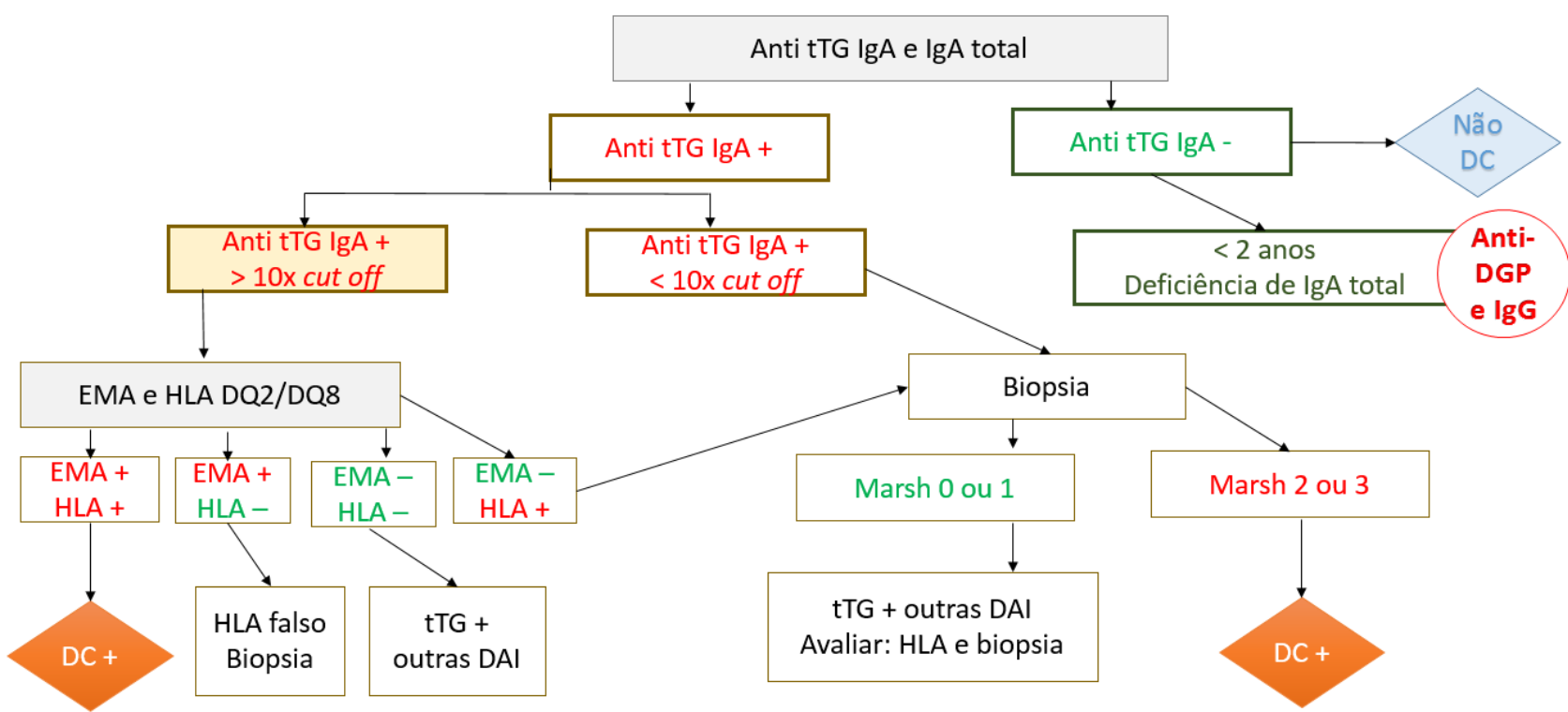

Figura 2 - Critérios diagnósticos para DC. Algoritmo recomendado pela ESPGHAN adaptado (HUSBY, 2012)

\subsection{Diagnóstico laboratorial da DC}

A imunidade adaptativa da DC ocorre a partir do aumento dos linfócitos $\mathrm{T}$ que apresentam HLA-DQ na mucosa intestinal, respondendo contra fragmentos de gliadina desamidada complexada com a transglutaminase tecidual. Por consequência, esse reconhecimento celular dispara a resposta imunomediada por linfócitos B, levando a densa 
infiltração de células produtoras de IgA contra os peptídeos de gliadina desamidada (MURCH, 2016) e contra a transglutaminase tecidual (KONING, 2005). Portanto, um marcador de doença celíaca simples é analisar a presença e quantidade de anticorpos antitransglutaminase IgA (DIETERICH et al., 1997; HUSBY, 2012; MURCH, 2016).

De acordo com as diretrizes da Sociedade Europeia de Gastroenterologia Pediátrica, Diretrizes Nutricionais e para o Diagnóstico de Doença Celíaca (European Society for Pediatric Gastroenterology, Hepatology, and Nutrition Guidelines for the Diagnosis of Coeliac Disease - ESPGHAN) publicado em 2012, o diagnóstico da DC não mudou nos últimos vinte anos, porém, durante esse tempo, a DC passou de doença enteropática incomum para uma doença com distúrbios multiorgânicos em pacientes geneticamente predispostos. $\mathrm{O}$ diagnóstico também evoluiu, disponibilizando testes de anticorpos específicos para DC, baseados principalmente em anticorpos para transglutaminase, anticorpos anti-endomísio e genotipagem molecular para identificar a presença dos genes HLA-DQ2 e HLA-DQ8 (HUSBY, 2012).

\subsubsection{Ensaios moleculares}

O teste genético para detectar a presença dos genes HLA-DQ2 e HLA-DQ8 é de grande valor preditivo negativo, ou seja, dificilmente o indivíduo que não possui esses genes, desenvolverá doença celíaca. Aproximadamente 30\% das pessoas possuem esses genes, porém, apenas 3 a 4\% desse grupo irá desenvolver a DC (ABADIE et al, 2011; CHANG \& GREEN, 2009; WOLTERS \& WIJMENGA, 2008; VIVES-PI et al, 2013).

A ESPGHAN recomenda o teste genético em casos de pacientes assintomáticos pertencentes ao grupo de risco, tais como filhos de celíacos, diabéticos tipo 1 e portadores de síndrome de Down, com o intuito de descartar a hipótese diagnóstica em casos duvidosos. Ou seja, se os genes não estiverem presentes, a chance de desencadear a DC é extremamente baixa (HUSBY, 2012), pois o HLA é responsável por 40\% do risco genético para a doença (TRYNCA et al, 2011).

\subsubsection{Ensaios sorológicos}

No passado, muitas incertezas a respeito dos testes sorológicos para DC foram levantadas, tais como sensibilidade e especificidade quando comparadas com outros testes 
sorológicos para detecção de doenças autoimunes (LEFFLER e SCHUPPAN, 2010). Atualmente, existem métodos com sensibilidade e especificidade comprovadamente elevadas, sendo utilizados nas sorologias para detecção e monitoramento da doença celíaca (GROSSMANN et al., 2016).

Os testes sorológicos na prática clínica para a DC são usados com frequência para identificar indivíduos sintomáticos ou assintomáticos que inicialmente necessitariam de exame de biópsia intestinal para confirmar o diagnóstico (LIONETTI et al., 2015). Testes positivos na sorologia apoiam o diagnóstico de doença celíaca.

Para o diagnóstico sorológico de doença celíaca são analisados os autoanticorpos contra endomísio (EMA), gliadina (AGA) e transglutaminase (tTG) (DIETERICH et al., 1997; GROSSMANN et al., 2016). O EMA e o anti-tTG apresentam sensibilidade em torno de 95\%, e especificidade em torno de100\% (DIETERICH et al., 1997).

Os testes anti-gliadina não são considerados de boa sensibilidade ou especificidade para serem usados no diagnóstico da DC (BAO, GREEN \& BHAGAT, 2012), mas recentemente estes testes passaram por modificações que permitem a detecção de anticorpos contra gliadina desamidada (anti-DGP) IgG e IgA, e são indicados nos casos de deficiência de IgA, quando são detectados anticorpos anti-DGP IgG (SCHUPPAN \& ZIMMER, 2013), e também são empregados como testes adicionais em pacientes que são negativos para outros testes sorológicos, mas que apresentam sintomas clínicos característicos de DC, principalmente em crianças com idade inferior a dois anos, quando são dosados anti-DGP IgA e IgG (HUSBY et al, 2012; SCHUPPAN \& ZIMMER, 2013).

A imunoglobulina mais utilizada para as sorologias EMA, AGA e tTG é a IgA (GROSSMANN et al., 2016), porém, em pacientes com concentrações baixas de IgA total, pode haver resultados falso-negativos para essas imunoglobulinas específicas (DIETERICH, 1997; DAHLBOM et al., 2005; CAJA et al., 2011; GROSSMANN et al., 2016). Em caso de deficiência na concentração de $\operatorname{IgA}$, pode ser usada como alternativa a dosagem de $\operatorname{IgG}$ para EMA, AGA e tTG (DAHLBOM et al., 2005; VERMEERSCH et al., 2012, HUSBY, 2012).

Dentre os ensaios sorológicos existentes, a determinação de anti-tTG IgA isoladamente pode ser usada como teste de triagem e para monitoramento da DC. É um analito de alta exatidão, o anticorpo contra a transglutaminase tecidual (anti-tTG) participa diretamente da patogênese da doença celíaca e não depende do observador, como é o caso do anti-endomísio (COLLIN et al., 2005; MONZANI et al., 2011). Outras considerações como precisão, confiabilidade e custo, a medição do anticorpo IgA contra transglutaminase (anti- 
tTG IgA), fazem com que esse teste seja recomendado para iniciar o diagnóstico da DC (HUSBY, 2012).

\subsubsection{Anti-transglutaminase (anti-tTG) IgA}

Em 1997, Dieterich e colaboradores, encontraram autoanticorpos contra tTG em amostras séricas de doentes celíacos, sugerindo mecanismo de indução autoimune após ingestão de glúten. A transglutaminase faz parte de uma família de enzimas cálcio dependente, encontrada tanto no interior quanto no exterior das células (AGA INSTITUTE, 2006). Essas enzimas modificam a glutamina em resíduos de aminas primárias (STAMNAES e SOLLID, 2015) e na DC está envolvida em diversas situações (ROSTOM et al., 2006).

A transglutaminase tecidual desempenha papel central na patogênese da DC, ela potencializa a imunogenicidade dos peptídeos do glúten (imunogênicos) por meio da desamidação que ocorre no intestino delgado (SCHUPPAN e ZIMMER, 2013). O produto dessa desamidação é ácido glutâmico, que promove a ligação de peptídeos do glúten ao HLADQ2 ou HLA-DQ8 potencializando a reação inflamatória das células T, sendo importante também no efeito destruidor de células T CD8+ na mucosa intestinal (VIVES-PI et al., 2013; BARDELLA et al., 2001; SCHUPPAN e ZIMMER, 2009). A presença dessas células T citotóxicas, induz apoptose de enterócitos, remodelação atrófica da mucosa e má absorção intestinal (SCHUPPAN e ZIMMER, 2009).

Várias são as razões pelas quais a pesquisa do anticorpo anti-tTG IgA tornou-se o primeiro teste sorológico para diagnóstico e acompanhamento de DC na maioria dos países (ROSTOM et al., 2005; HILL et al., 2004; HUSBY, 2012; AGA INSTITUTE, 2006). Alguns estudos apontaram a especificidade e sensibilidade desse ensaio, acima de $95 \%$ e 90 a 96\%, respectivamente (VERMEERSCH et al., 2012; UTIYAMA et al, 2002; ROSTOM, 2005; AGA INSTITUTE, 2006). A positividade de anti-tTG IgA está altamente associada com DC em crianças e adolescentes (ROSTOM, 2005; LEWIS, 2006). Outro fator de grande importância na escolha de anti-tTG IgA como teste de triagem, é para confirmação de DC para indivíduos assintomáticos e exclusão da doença em pessoas sintomáticas (LEWIS, 2006).

Outra variável que deve ser levada em consideração, é a quantificação da IgA total, que deve ser analisada paralelamente com anti-tTG IgA, para evitar interpretações erradas de resultados falsamente negativos, pois a deficiência de IgA total afeta diretamente os 
resultados de anti-tTG IgA (DAHLBOM et al., 2005; HILL et al., 2005; ROSTOM et al., 2005; GROSSMANN et al., 2016).

\subsubsection{Anticorpos anti-gliadina (anti-AGA)}

O anticorpo anti-gliadina foi o primeiro marcador sorológico associado a DC, pois a presença do anticorpo estava diretamente relacionada com biópsias alteradas, o que não ocorria em biópsias normais, conforme descrito por O'Farrelly e colaboradores em 1983. A pesquisa de autoanticorpos da classe IgG contra a gliadina desamidada (anti-DGP) está substituindo a pesquisa de anti-gliadina (anti-AGA), isso porque desamidação da gliadina por meio da atividade da transglutaminase tecidual, está presente apenas em indivíduos que possuem DC (SCHUPPAN e ZIMMER, 2013).

Apesar da precisão de anti-tTG no diagnóstico da DC, a sensibilidade é reduzida quando testado em crianças menores de dois anos. Muitas crianças que apresentam resultados negativos para anti-tTG IgA, podem apresentar resultados positivos para gliadina desamidada, sendo considerada como grande vantagem no auxílio do diagnóstico de DC (MOZO et al. 2012).

As imunoglobulinas anti-gliadina (AGA) envolvidas na resposta imune são as de classe IgA e IgG. A AGA IgA é mais comumente utilizada e possui sensibilidade maior que a classe IgG (ROSTOM et al., 2006), embora o teste de AGA possua sensibilidade e especificidade menor que outros marcadores sorológicos (HILL, 2005). A metodologia mais aplicada para a dosagem de AGA é o ELISA (TONUTTI et al., 2009).

\subsubsection{Anticorpos anti-endomísio (anti-EMA)}

Anticorpos anti-endomísio (EMA) reagem contra as miofibrilas que são semelhantes à reticulina no tecido conjuntivo que envolve as fibras de músculo liso no trato gastrointestinal de primatas, substrato empregado no teste (CHORZELSKI, 1984).

O EMA é mensurado por imunofluorescência indireta, utilizando como substrato, tecido de esôfago de macaco ou cordão umbilical humano. Dependendo do padrão de colocação observado em microscopia de fluorescência, o resultado é positivo. Essa técnica possui a desvantagem de ser dependente do microscopista (ROSTOM et al., 2006) e é limitada, por não afirmar de fato, se o paciente possui ou não doença celíaca (ROSTOM, A.; MURRAY, J.; KAGNOFF, M., 2006; CAJA, 2011; VIVES-PI, 2013). 
Com base na literatura, os melhores testes para este propósito são o EMA IgA e tTG IgA, ambos altamente sensíveis e específicos (CHORZELSKI, 1984; DIETERICH, 1997; COLLIN, 2005). Em contrapartida, em indivíduos sintomáticos nos quais a evidência clínica não seja clássica para a DC, a biópsia intestinal deve ser considerada, mesmo se o teste sorológico é negativo (HILL, 2005)

\subsection{Metodologia de ELISA}

O termo Enzyme Linked Immuno Sorbent Assay (ELISA) caracteriza-se por ser um ensaio heterogêneo, cujo princípio básico é a imobilização de um dos reagentes em fase sólida, enquanto outro reagente, geralmente o anticorpo, pode ser ligado a uma enzima, com preservação das atividades enzimática e imunológica do anticorpo (FERREIRA E MORAES, 2013).

Para a fase sólida, o suporte mais empregado são as placas de polietileno, nas quais é possível adsorver antígenos e/ou anticorpos. Estas placas possuem 96 poços e podem realizar múltiplos ensaios, além de permitir a utilização de equipamentos automatizados. O grau de pureza do antígeno ou do anticorpo empregado na fase sólida é muito importante, pois qualquer molécula inespecífica poderá interferir nos resultados (DIAMANDIS E CHRISTOPOULOS, 1996).

Para a pesquisa de antígeno, o anticorpo utilizado na sensibilização da placa deve ter alta afinidade e curva dose-resposta, determinando por meio dessa curva os resultados proporcionais ao antígeno presente na amostra-teste. Para a pesquisa de anticorpos, o antígeno deve estar livre de impurezas, podendo-se utilizar antígenos purificados por cromatografia de alta afinidade com anticorpos monoclonais, peptídeos sintéticos ou antígenos recombinantes (CROWTHER, 1995).

O objetivo do ensaio é a quantificação ou verificação da presença de um antígeno ou anticorpo. Os métodos de expressão dos resultados do teste enquadram-se em duas categorias: quantitativos e qualitativos. Nos resultados quantitativos, como sugerido pelo nome, ocorre quantificação da concentração da amostra em análise em Densidade Óptica (D.O.), e os resultados são expressos em Unidade Arbitrária (UA), Unidades Internacionais (UI) ou Unidades (U). Nos qualitativos, os resultados obtidos são classificados como positivo/negativo ou reagente/não reagente considerando-se os valores da absorbância obtidos por D.O. ou a coloração da reação final (DIAMANDIS e CHRISTOPOULOS, 1996). 
Para a pesquisa de antígenos, é possível obter as concentrações por meio de uma amostra referência chamada padrão, empregada para construir uma curva de calibração doseresposta, calculada a partir da concentração do padrão versus absorbância ou densidade ótica.. $\mathrm{Na}$ pesquisa de anticorpos a quantificação é mais complexa, pois além de serem heterogêneos quanto à sua afinidade e propriedades físico-químicas, os anticorpos são geralmente ensaiados em uma faixa de concentração mais ampla do que a dos antígenos. Além disso, a afinidade dos anticorpos varia com a concentração, sendo maior em amostras mais diluídas (efeito prózona). Essas diferenças devem ser consideradas ao expressar os resultados e determinar o limiar de reatividade ou cut-off, empregado para definir a positividade e negatividade do ensaio (FERREIRA e MOARES, 2013).

A extensa utilização do método de ELISA deve-se à facilidade na obtenção dos resultados por reação de cor que pode ser observada a olho nu, ou utilizando espectrofotômetros multicanais. O uso da adsorção em fase sólida (nas placas de polietileno), fornece ao método ótima flexibilidade no desenho de imunoensaios. O método de ELISA pode ser classificado em: direto, indireto, sanduíche (direto e indireto) e competitivo (CROWTHER, 1995).

\subsubsection{Método ELISA indireto}

O método ELISA indireto é amplamente utilizado na pesquisa de anticorpos e possui a grande vantagem de utilizar um único conjugado. Neste método, os 96 poços da placa de polietileno são sensibilizados com o antígeno que reage com os anticorpos da amostra. $\mathrm{O}$ conjugado anti-imunoglobulina humano reage com o anticorpo capturado pelo antígeno e a reação é revelada com a solução cromógena. A reação é interrompida e a intensidade da cor é estimada. A intensidade da cor da solução é proporcional à quantidade de anticorpo e a leitura pode ser realizada a olho nu ou por meio de algum sistema espectrofotométrico de placas multicanais (FERREIRA e MORAES, 2013).

\subsection{Metodologia de quimioluminescência}

Os ensaios quimioluminescentes foram inicialmente testados como alternativas aos radioisótopos na década de 70. A quimioluminescência caracteriza-se pela emissão de luz após reação química de oxidação utilizando enzimas, tais como, fosfatase alcalina e 
peroxidase. A energia química gerada como resultado da dissociação de ligações fracas, produz compostos intermediários em um estado eletronicamente excitado que, quando retornam ao estado de energia inicial, emitem luz (DIAMANDIS e CHRISTOPOULOS, 1996).

Existem diversas moléculas com características estruturais que produzem quimioluminescência. $\mathrm{O}$ luminol e $\mathrm{o}$ isoluminol foram as primeiras moléculas quimioluminescentes a serem testadas em um imunoensaio. O grupo 5-amino de luminol proporciona um local conveniente de ligação de antígenos e anticorpo (DIAMANDIS e CHRISTOPOULOS, 1996).

\subsection{Metodologias sorológicas para mensurar anti-transglutaminase IgA na detecção de doença celíaca}

O diagnóstico precoce é de extrema importância para que as manifestações clínicas decorrentes da doença possam ser minimizadas com dieta livre de glúten (SULKANEN et al., 1998). Dieterich e colaboradores (1997), identificaram que a $\operatorname{IgA}$ reage com a transglutaminase tecidual em indivíduos com doença celíaca, sugerindo que a detecção desse autoanticorpo poderia ser ferramenta útil no diagnóstico e acompanhamento da doença.

Sulkanen e colaboradores (1998), desenvolveram o ensaio pela metodologia ELISA, com o objetivo de obterem teste sorológico tão sensível quanto específico. Eles concluíram que a identificação de autoanticorpos contra transglutaminase $\operatorname{IgA}$ pela metodologia de ELISA é altamente preciso para detectar doença celíaca não tratada. A metodologia de ELISA foi pioneira para analisar anti-tTG IgA (SULKANEN et al., 1998no). Leffler e Schuppan (2010) realizaram um estudo a respeito das sorologias na doença celíaca, onde obtiveram sensibilidade e especificidade de $98 \%$ para anti-tTG IgA.

Esse fenômeno pode ser definido de uma maneira simples como reações químicas que emitem luz. Essas reações se dão pela transição de elétrons a partir de seu estado fundamental para um estado eletrônico excitado, acompanhado geralmente por alterações de rotação vibracional na molécula, emitindo fotóns de luz (HILL et al., 2005; ROSTAMI et al., 1999).

$\mathrm{O}$ ensaio anti-tTG IgA é aceito como a melhor ferramenta de rastreio para DC, e até pouco tempo só poderia ser realizado utilizando a metodologia de ELISA, mas recentemente passou a ser dosado empregando a metodologia de quimioluminescência, apresentando várias 
vantagens quando comparada ao método considerado como referência, demonstrado no Quadro 1 (AGA INSTITUTE, 2006).

Quadro 1 - Vantagens da metodologia quimioluminescente frente a metodologia ELISA.

Vantagens da quimioluminescência frente a metodologia de ELISA

Facilidade operacional

Realiza vários imunoensaios simultaneamente na mesma amostra

Alta sensibilidade

Alta especificidade

No caso do anti-tTG, mensura a concentração de anticorpo IgA

Intervalo de medição muito maior

Menor volume de amostras, favorecendo pacientes pediátricos

Tempo de reação diminuído

Menor produção de resíduos sólidos e líquidos

A facilidade da dosagem da anti-tTG, aliado a elevadas sensibilidade e especificidade na população pediátrica e adulta, torna esse teste sorológico na melhor escolha para avaliação inicial dos indivíduos com suspeita de intolerância permanente ao glúten (LUDVIGSSON et al., 2014; BRASIL, MINISTÉRIO DA SAÚDE, 2015).

A quimioluminescência é uma metodologia rápida, eficaz e com alto desempenho analítico, ou seja, possui alta sensibilidade e especificidade (AITA et al., 2013). Verificando a necessidade de inovação, otimização de tempo e fluxos de trabalho além de metodologia dinâmica e atual, o trabalho realizou uma comparação entre ELISA e quimioluminescência, a fim de garantir a equivalência diagnóstica entre esses dois ensaios, fornecendo dessa forma, mais uma opção analítica para a mensuração de anti-tTG IgA.

\subsection{Parâmetros de validação de ensaio}

A avaliação da qualidade dos ensaios laboratoriais é de grande interesse de investigação clínica e epidemiológica, e para isso, vários parâmetros devem ser analisados para validação de um teste diagnóstico. Nesse estudo foram avaliados parâmetros intrínsecos, que avaliaram o teste de acordo com o método referência (ELISA), tais como sensibilidade, especificidade e eficiência, como demostrado na Figura 3 (VAZ, TAKEI e BUENO, 2007; FERREIRA e MOARES, 2013). 
Já os parâmetros extrínsecos avaliaram a reprodutibilidade, acurácia e a precisão da quimioluminescência. Foram avaliados também os parâmetros como os valores preditivos negativos e positivos do método referência na qual a população em estudo está sendo avaliada (FERREIRA e MORAES, 2013).
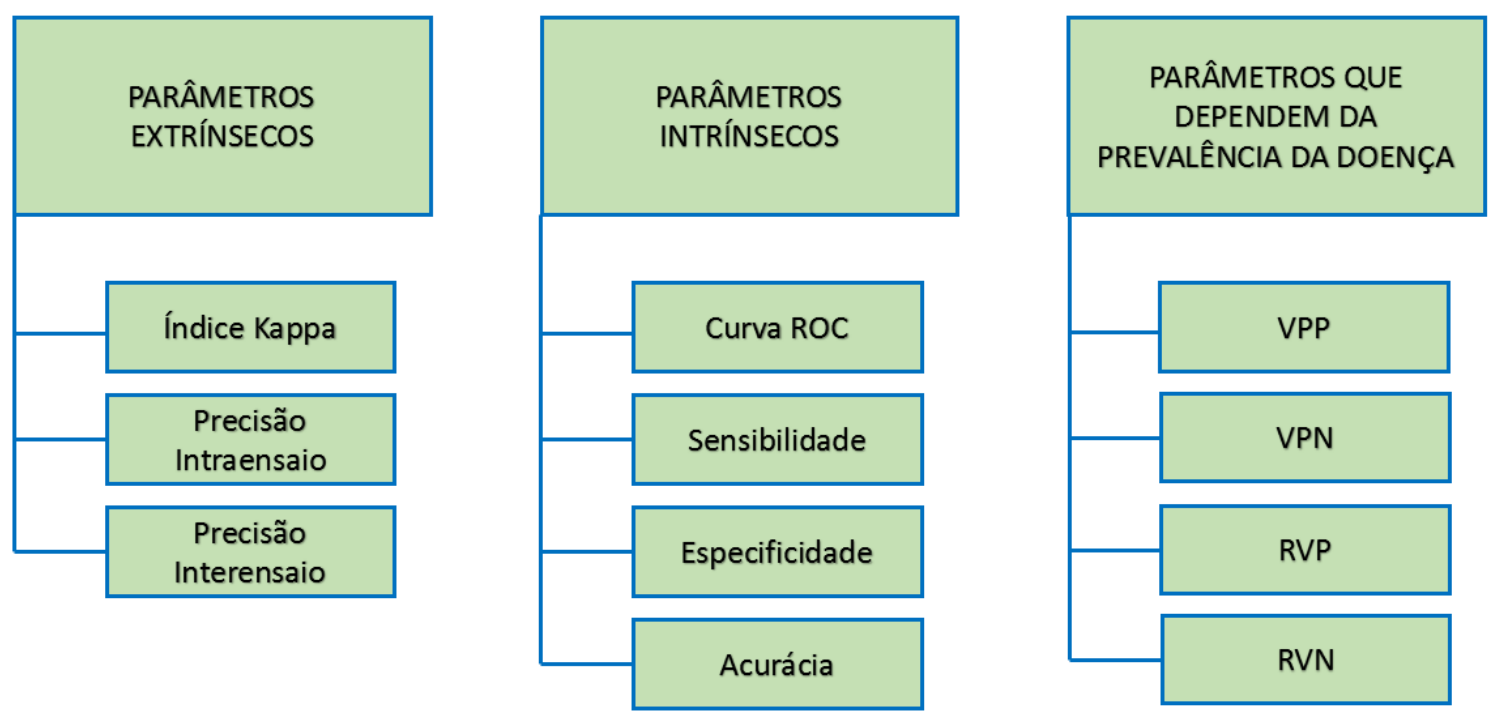

Figura 3 - Parâmetros de validação de ensaio adaptado (FERREIRA e MORAES, 2013)

A avaliação dos parâmetros citados, garante que o método que está sendo validado seja capaz de garantir os resultados laboratoriais de acordo com a condição clínica do paciente, seja ele doente ou saudável (LINDEN, 2006; FERREIRA e MORAES, 2013).

\subsubsection{Parâmetros extrínsecos}

Os parâmetros extrínsecos determinam a existência de concordância, repetitibilidade, reprodutibilidade e estabilidade dos resultados obtidos a partir de amostras com concentrações conhecidas, com o objetivo de avaliar os erros experimentais pertinentes ao método (FERREIRA e MORAES, 2013).

\subsubsection{1. Índice kappa $(\kappa)$}

É uma medida de concordância que permite realizar uma avaliação interensaio e mede o grau de concordância que seria esperado, por meio da divisão da diferença entre a concordância observada e a concordância esperada pelo acaso, onde a concordância esperada 
pelo acaso é a maior diferença possível entre concordância observada e esperada (FERREIRA e MORAES, 2013).

Os graus de concordância podem ser classificados como ruim $(0,00$ a 0,20$)$, fraca $(0,21$ a 0,40$)$, moderada $(0,41$ a 0,60$)$, substancial $(0,61$ a 0,80$)$ e quase perfeita $(0,81$ a 1,00$)$.

\subsubsection{Precisão intraensaio}

Precisão intraensaio é a capacidade do analito apresentar a menor variação entre resultados quando repetido diversas vezes na mesma amostra (WALLACH, 2013).

\subsubsection{Precisão intrerensaio}

Precisão intraensaio é a capacidade do analito apresentar a menor variação entre resultados quando repetido diversas vezes na mesma amostra, em dias alternados (WALLACH, 2013).

\subsubsection{Parâmetros intrínsecos}

Os parâmetros extrínsecos determinam a capacidade do teste em detectar a real situação da população em relação à doença estudada (FERREIRA e MORAES, 2013).

\subsubsection{Curva Receiver Operating Characteristic (Curva ROC)}

A curva ROC (Receiver Operating Characteristic) é uma ferramenta que analisa o desempenho dos testes diagnósticos, levando em consideração a precisão e exatidão do ensaio (METZ, 1978). A precisão (parâmetros extrínsecos) está diretamente relacionada com a dispersão dos valores em sucessivas observações, enquanto a exatidão (parâmetros intrínsecos) refere-se à representação da estimativa do verdadeiro valor esperado. Porém, conhecer os resultados "falsos negativos" e "falsos positivos", é mais importante que conhecer apenas a precisão do analito, pois eles são dependentes do limiar de decisão (cut off) (METZ, 1978). Para validar um ensaio diagnóstico, a descrição dos princípios da curva ROC, possui significativa superioridade em relação a outras medidas de acurácia (METZ, C.; HERMAN, B.; ROE, C., 1998).

Essa ferramenta é construída por meio de gráfico simples e robusto, que permite determinar e avaliar a especificidade e sensibilidade para cada ponto de corte (cut off) (METZ, 2008). Define as características operacionais de um teste com valores numéricos 
contínuos a partir da base de dados formada por um conjunto de amostras que assumem determinada característica diagnóstica, neste caso, resultados positivos ou negativos aos quais são chamamos de classificadores (LINDEN, 2006).

As métricas são determinadas de acordo com o cruzamento da matriz de contingência (Quadro 2). O tp rate (relação entre os resultados verdadeiros positivos e o total de resultados positivos - eixo Y) e $f p$ rate (relação entre os resultados falsos positivos e o total de resultados negativos - eixo X) servem de base para a construção do espaço ROC. As métricas, precisão (que é a taxa de acerto) e acurácia (taxa de acerto dos dois classificadores e o número total de análises) são então plotados bidimensionalmente na curva ROC, representando dessa forma, o desempenho global do ensaio (DEEKS, 1999; LINDEN, 2006).

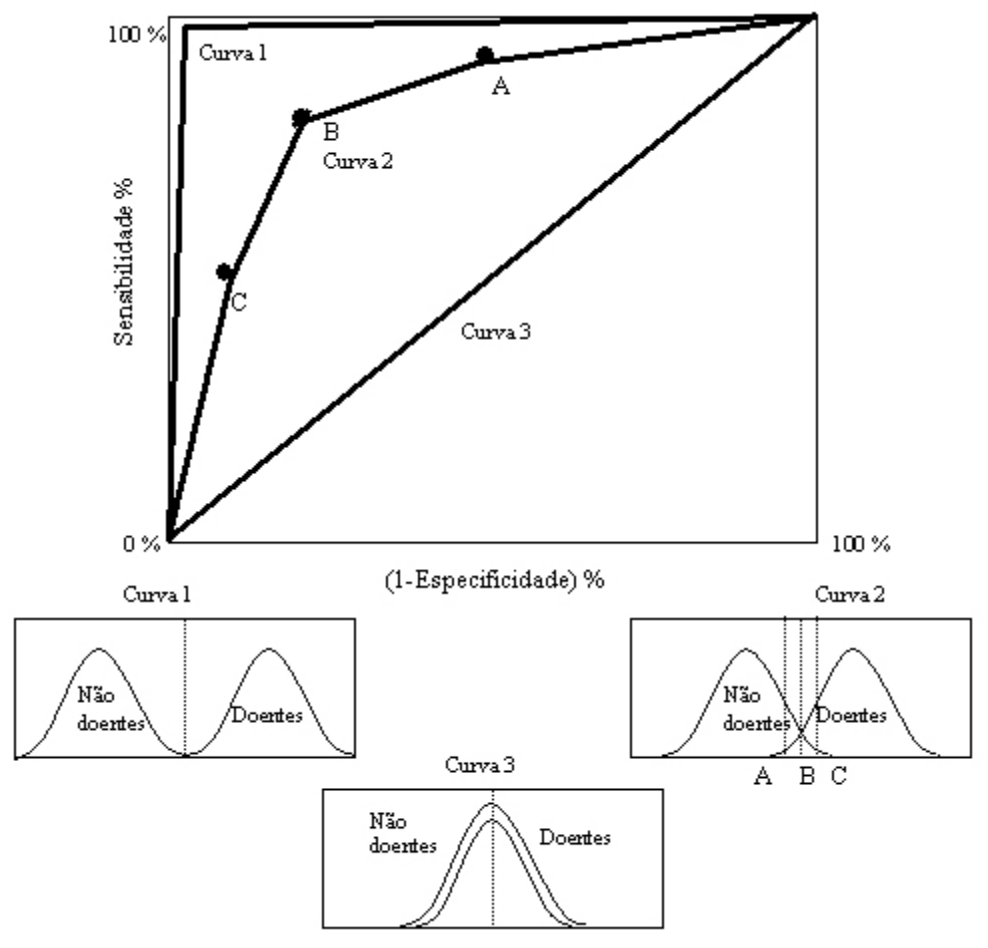

Figura 4 - Curvas ROC. A curva 1 ilustra alta sensibilidade e alta especificidade, distinguindo bem a população doente dos não doentes. A curva 2 demonstra equilíbrio entre sensibilidade e especificidade, com margem baixa para indivíduos doentes e não doentes. A curva 3, não distingue pacientes de acordo com a doença, a linha central da curva 3 , significa $50 \%$ da acurácia do ensaio

\subsubsection{1. Área sob a curva ROC}

A área sob a curva analisa o desempenho do ensaio diagnóstico (ENG, 2012; METZ, 2008). A área sob a curva, define a probabilidade do teste em detectar os verdadeiros positivos e os verdadeiros negativos, ou seja, expressa a acurácia do ensaio (LINDEN, 2006). A linha em diagonal (45 graus) expressa a acurácia em $50 \%$. A curva ROC ideal é aquela que 
arqueia o mais próximo do eixo y (probabilidade dos verdadeiros positivos) e mais longe do eixo x (probabilidade dos falsos positivos) (DEEKS, 1999; LINDEN, 2006).

Para interpretar o desempenho analítico da área sob a curva como teste acurado, o ensaio deve possuir alto índice de precisão (área sob a curva >0.9), baixo índice de erro padrão $(<0,01)$ e $p<0,0001$ (FERREIRA e MORAES, 2013).

\subsubsection{Sensibilidade}

É a capacidade que o ensaio laboratorial apresenta de detectar os indivíduos verdadeiramente positivos (FERREIRA e MORAES, 2013).

\subsubsection{Especificidade}

É a capacidade que o ensaio laboratorial apresenta de detectar os indivíduos verdadeiramente negativos (FERREIRA e MORAES, 2013).

\subsubsection{Eficiência ou acurácia}

É a relação do somatório dos resultados verdadeiros positivos e verdadeiros negativos. Nesse caso, quanto mais próximo de 1, melhor é o teste em estudo (FERREIRA e MORAES, 2013).

\subsubsection{Parâmetros que dependem da prevalência da doença}

Os valores preditivos dos resultados positivos e negativos dependem não apenas da sensibilidade e da especificidade do ensaio, mas também da prevalência da doença que está sendo diagnosticada no estudo (VAZ, TAKEI e BUENO, 2007; FERREIRA e MORAES, 2013; PEREIRA, 1995).

\subsubsection{Valor preditivo de um resultado positivo (VPP)}

O valor preditivo de um resultado positivo pode ser calculado pela proporção de indivíduos doentes entre os resultados positivos obtidos no teste em estudo, refere-se então, à probabilidade de doença quando o resultado do ensaio é positivo (FERREIRA e MORAES, 2013; PEREIRA, 1995). 
1.10.3.2. Valor preditivo de um resultado negativo (VPN)

O valor preditivo de um resultado positivo pode ser calculado pela proporção de indivíduos sadios entre os resultados negativos obtidos no teste em estudo, refere-se então, à probabilidade de não ocorrência da doença quando o resultado do ensaio é negativo (FERREIRA e MORAES, 2013; PEREIRA, 1995).

\subsubsection{Razão de verossimilhança positiva (RVP)}

É a probabilidade do resultado esperado para um indivíduo doente com a probabilidade do mesmo resultado em um indivíduo não portador da doença. Neste caso, quanto melhor o teste, maior a RVP (FERREIRA e MORAES, 2013; PEREIRA, 1995).

\subsubsection{4.. Razão de verossimilhança negativa $(R V N)$}

É a probabilidade do resultado esperado para um indivíduo sadio com a probabilidade do mesmo resultado em um indivíduo portador da doença. Neste caso, quanto melhor o teste, menor a RVN (FERREIRA e MORAES, 2013; PEREIRA, 1995). 


\section{OBJETIVOS}

\subsection{Objetivo geral}

Comparar a eficácia de quimioluminescência e ELISA, que é o método referência, na dosagem sorológica de anticorpos anti-transglutaminase IgA.

\subsection{Objetivos específicos}

Avaliar a performance analítica do ensaio de quimioluminescência empregada na dosagem de anti-transglutaminase $\operatorname{IgA}$ (anti-tTG IgA) para o diagnóstico laboratorial da doença celíaca utilizando o cálculo de Índice Kappa, especificidade, sensibilidade e acurácia.

Avaliar a performance clínica por meio do cálculo de Valor Preditivo Positivo e Negativo, e a Razão de Verossimilhança, fatores associados à positividade na dosagem de anti-transglutaminase IgA (anti-tTG IgA), além do Risco Relativo e Odds Ratio que avaliam o risco/chance de desenvolvimento da Doença Celíaca em pacientes que apresentem positividade para tTG IgA. 


\section{MATERIAL E MÉTODOS}

\subsection{Amostras séricas}

Neste estudo de avaliação de testes diagnósticos, foram analisadas 182 amostras de soro de pacientes, oriundas do biorepositório do Laboratório de Pesquisas em Doença Celíaca (LABDC), localizado no Laboratório Interdisciplinar de Biociências (LabIBC), do Departamento de Patologia da Faculdade de Medicina, da Universidade de Brasília (UnB). O estudo foi aprovado pelo Comitê de Ética da Faculdade de Ciências da Saúde da Universidade de Brasília, sob o número 649.664.

Todas as amostras de soro foram mensuradas empregando duas metodologias distintas, Enzyme Linked Immuno Sorbent Assay (ELISA) e quimioluminescência, empregando os equipamentos Best-2000® e Bio-Flash® ambos da INOVA Diagnostics Inc. (San Diego, CA, Estados Unidos).

Para o processo de seleção das amostras de soro a serem incluídas no estudo para a dosagem de anticorpos anti-transglutaminase da classe $\operatorname{IgA}$ (tTG IgA), foram separadas 11 amostras que inicialmente foram dosadas por ELISA e apresentaram resultados positivos no teste de tTG IgA (Cut-off acima de $30 \mathrm{U}$ ) e 171 amostras com resultados negativos (Cut-off abaixo de $29 \mathrm{U}$ ), que juntas totalizam as 182 amostras empregadas no estudo.

Após a dosagem pela metodologia de ELISA, as mesmas amostras foram processadas empregando a metodologia de quimioluminescência. Em ambos os ensaios metodológicos foram empregadas as normas do fabricante.

\subsection{Anti-transglutaminase IgA por ELISA indireto}

O ensaio de anti-transglutaminase IgA (tTG IgA) pelo método de ELISA (INOVA Diagnostics, Inc., San Diego, CA, Estados Unidos), foi realizado no analisador de imunoensaio totalmente automatizado empregando metodologia de ELISA indireto. Para a realização do teste tTG $\operatorname{IgA}$, todos os reagentes foram colocados a temperatura ambiente (20 a $26{ }^{\circ} \mathrm{C}$ ). Os poços da microplaca utilizados para a realização do ensaio tTG IgA estavam sensibilizados com antígeno humano tTG recombinante. No início do ensaio, $100 \mu \mathrm{L}$ de tampão fosfato (PBS) pH 7,0 foi adicionado em cada um dos dois primeiros poços destinados ao branco da amostra e $100 \mu \mathrm{L}$ por poço de controle positivo alto, positivo baixo e controle 
negativo foram adicionados em duplicata nos poços subsequentes da placa sem diluição prévia. Em seguida as amostras de pacientes a serem analisadas foram diluídas 1:100 em solução de tampão fosfato (PBS), e foram pipetadas $100 \mu \mathrm{L}$ nos poços subsequentes. Após a adição de controles e amostras, a placa foi incubada a $37 \pm 2{ }^{\circ} \mathrm{C}$ durante 30 minutos.

Os autoanticorpos presente nas amostras de soro dos pacientes que reconhecem o antígeno transglutaminase humano, ligam-se durante essa primeira incubação. Após esse período os poços foram lavados $3 x$ com $300 \mu \mathrm{L}$ /poço de solução de lavagem fornecida pelo kit, para a remoção de anticorpos que não se ligaram. Na etapa seguinte, foi adicionado 100 $\mu \mathrm{L}$ do conjugado de cabra anti-IgA marcado com peroxidase purificada em cada poço da placa, exceto no branco da amostra que foi incubado por 30 minutos a $37 \pm 2{ }^{\circ} \mathrm{C}$. O conjugado não ligado foi removido por uma nova lavagem nas mesmas condições descritas para a primeira lavagem.

Em seguida foi adicionado100 $\mu \mathrm{L}$ substrato marcado com tetrametilbenzidina (TMB) para a formação de um produto de cor azul, cuja intensidade é proporcional à concentração de anticorpos presentes na amostra. A reação foi interrompida pela adição de $100 \mu \mathrm{L}$ de ácido sulfúrico 0,344 M em cada poço que produziu a formação de uma cor amarela, indicando o fim da reação (Figura 5). A leitura foi realizada empregando um filtro com comprimento de onda de $450 \mathrm{~nm}$ e filtro de referência em $620 \mathrm{~nm}$.

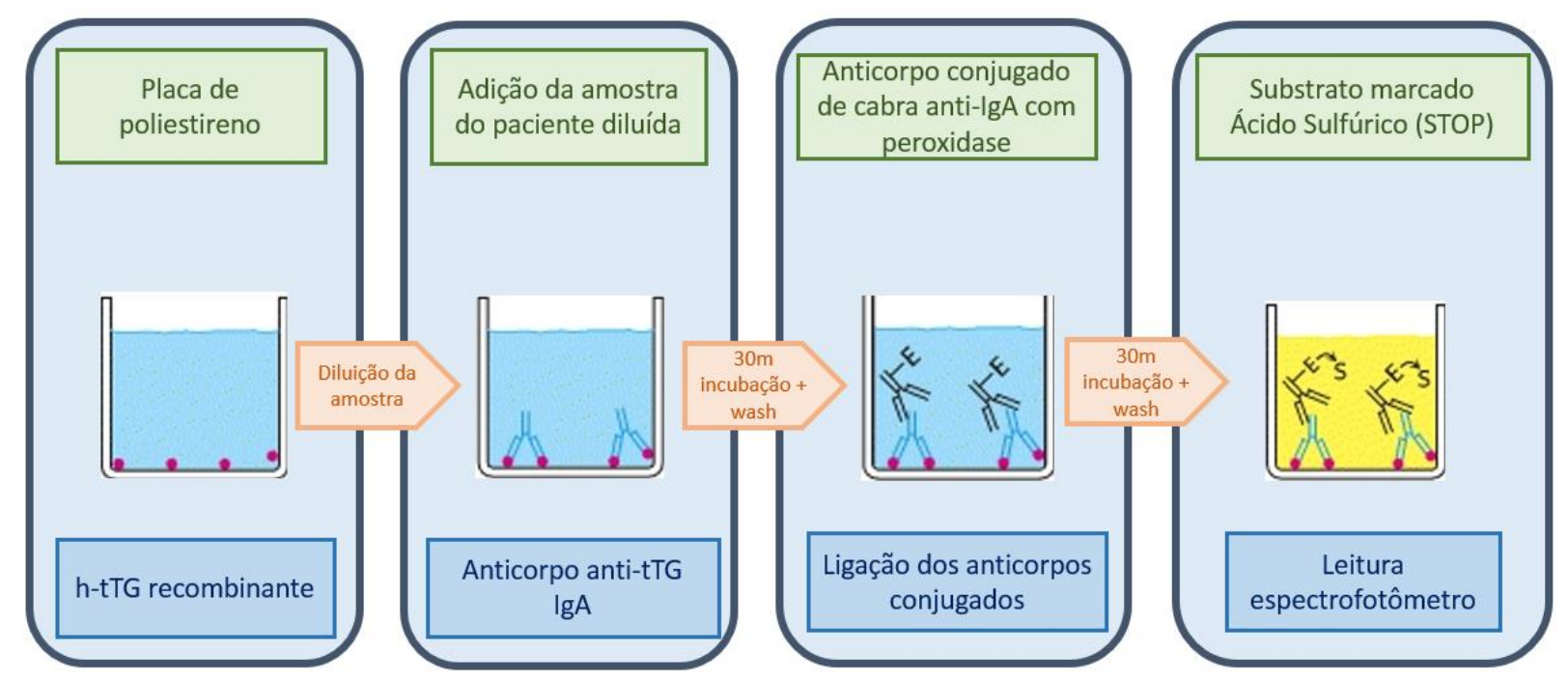

Figura 5 - Ilustração da metodologia de ELISA indireto para análise de anti-tTG IgA Fonte: FERREIRA e MORAES, 2013 com adaptações.

Para o cálculo dos resultados o equipamento plotou uma regressão não linear considerando para obtenção do resultado, a D.O. da amostra dividido pela D.O. do controle 
positivo baixo, e este valor foi multiplicado pelo valor do controle positivo baixo e expresso em unidades (U).

A curva de calibração permite um intervalo de leitura de no mínimo 1,23 U até no máximo 100,00 U, a partir dessa concentração, a amostra deverá submeter-se a uma diluição para a mensuração real do anticorpo anti-tTG IgA.

De acordo com os valores de referência do fabricante e a análise estatística da Receiver Operating Characteristic (Curva ROC), as amostras com resultados abaixo de $30 \mathrm{U}$ foram consideradas negativas e resultados acima de $30 \mathrm{U}$ consideradas positivas.

\subsection{Anti-transglutaminase IgA por quimioluminescência}

$\mathrm{O}$ ensaio de anti-transglutaminase IgA QUANTA Flash h-tTG IgA (INOVA Diagnostics, Inc., San Diego, CA, Estados Unidos) foi realizado no equipamento de imunoensaios totalmente automatizado, que emprega a metodologia de quimioluminescência Bio-Flash® fabricado pela INOVA Diagnostics Inc. (San Diego, CA, Estados Unidos). O princípio de reação dos ensaios desse sistema foi recentemente descrito, e um desenho esquemático da reação pode ser visualizado na Figura 6 (MAHLER et al., 2016).

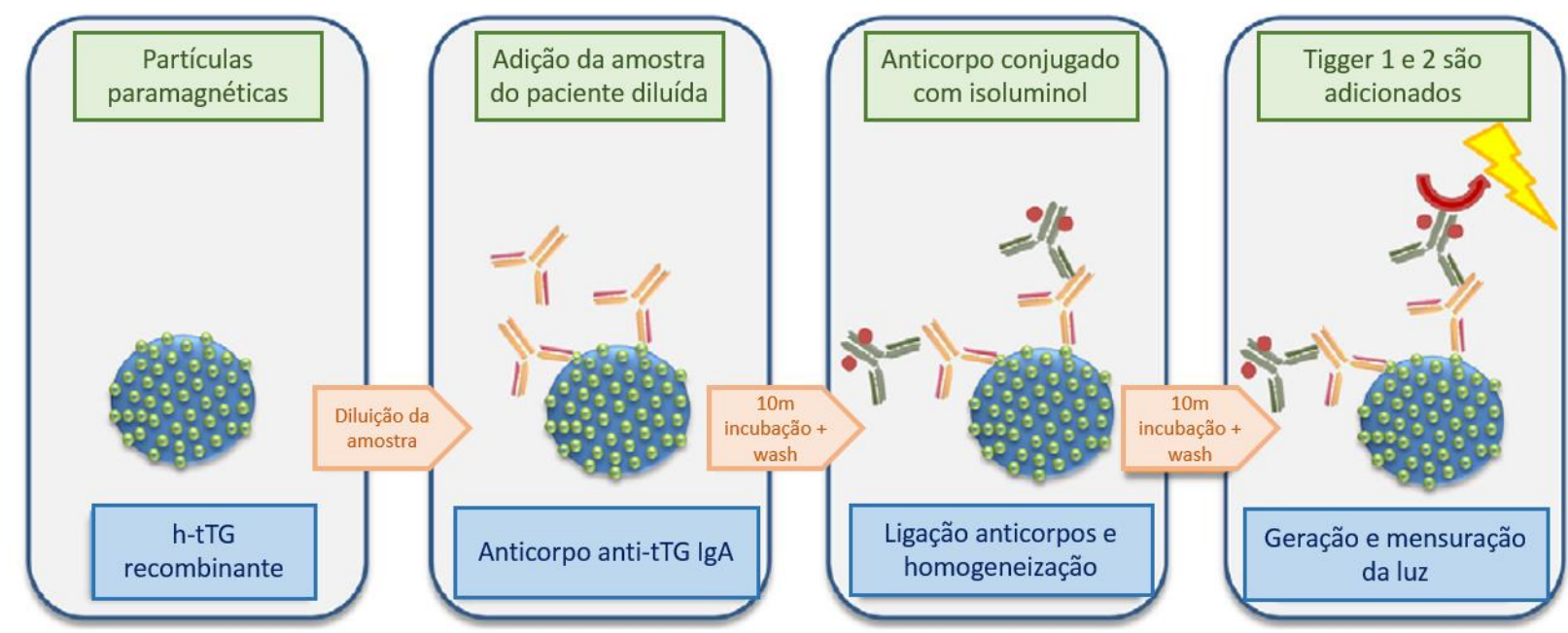

Figura 6 - Esquema de ensaio simplificado do procedimento realizado automaticamente pela quimioluminescência. Adaptado de MAHLER et al., 2016

O procedimento envolve três reações: captura do anticorpo de interesse a partir da amostra por meio de antígeno acoplado às esferas paramagnéticas, reconhecimento com o anticorpo marcado com isoluminol e a medição quimioluminescentes. Os passos são separados por duas lavagens.

Para mensurar anti-transglutaminase IgA por quimioluminescência no equipamento Bio-Flash ${ }^{\circledR}$, foram necessários os seguintes materiais: A - Kit com cartucho de reagente de quimioluminescência, contendo: $a$ - Esferas paramagnéticas revestidas de h-tTG (antígeno 
transglutaminase humano recombinante), $b$ - Tampão de ensaio: contendo tampão salina Tris, Tween 20, estabilizadores proteicos e conservantes e c - Marcador IgA (anticorpo IgA anti-humano marcado com isoluminol, contendo tampão, estabilizadores e conservante); BSystem rinse: fosfato surfactante e azida sódica (menos de 0,1\%); C - Trigger 1: hidróxido de sódio; D - Trigger 2: peróxido de uréia; E - Cubetas de polietileno; F - Calibradores e G Controles.

Antes de inserir o cartucho de reagente quimioluminescente, foi necessário realizar a suspensão das partículas paramagnéticas com a solução tampão. A solução tampão foi adicionada ao compartimento do cartucho que continha as esferas paramagnéticas, que foram resuspensas e homogeneizadas usando a pipeta de transferência que compõe o kit. As esferas paramagnéticas, são revestidas com o antígeno transglutaminase humano recombinante (htTG). Após a ressuspensão, o reagente está pronto para uso no equipamento Bio-Flash®.

Após a inicialização mecânica do equipamento e carregamento do reagente no aparelho, é possível inserir as amostras. $\mathrm{O}$ instrumento dilui as amostras de soro utilizando o "system rinse" 1:17 em uma cubeta de polietileno (específica para esse equipamento). Em seguida o soro diluído, tampão do ensaio e as esferas paramagnéticas de h-tTG são transferidos para uma segunda cubeta e misturados. Essa mistura é incubada a $37^{\circ} \mathrm{C}$. Após a incubação, as esferas são magnetizadas por meio de imãs (impedindo a sucção da reação pelo sistema de lavagem das reações) e lavadas três vezes com o rinse, afim de eliminar anticorpos inespecíficos. Em seguida, é adicionado à cubeta o marcador IgA anticorpo anti-humano conjugado de isoluminol (marcador quimioluminescente) e incubado novamente a $37^{\circ} \mathrm{C}$. Após a incubação, as esferas são magnetizadas e lavadas. A reação luminescente ocorre logo após a adição dos reagentes Trigger 1 e Trigger 2 (reagentes ativadores) à cubeta. A luz produzida a partir dessa reação é medida como Relative Ligth Unit (RLU) pelo luminômetro do aparelho. A quantidade de luz produzida é proporcional a quantidade de conjugado de isoluminol ligado, que por sua vez é proporcional a quantidade de anticorpos antitransglutaminase ligados à esfera paramagnética.

Para o cálculo dos resultados das amostras faz-se necessária a calibração da curva do ensaio. Ou seja, a cada novo lote, o cartucho de reagente deve ser calibrado. Os calibradores possuem concentrações conhecidas e são apresentados em dois níveis, um baixo e um alto. Ao inserir o tubo do calibrador no aparelho, a informação sobre as concentrações de cada nível, são inseridas automaticamente através da leitura do código de barras impresso no tubo. Cada calibrador será dosado em triplicata, e após essas análises, o software exigirá a validação da 
calibração pelo analista, que manualmente valida a curva. Uma vez aceita, a calibração está válida para mensurar as amostras. O cálculo é realizado a partir da quantificação de luz emitida (RLU) pela reação da amostra. As RLUs são projetadas para a curva calibrada, que refletirá a concentração diretamente proporcional a quantidade de luz emitida pela reação quimioluminescente.

A calibração para o ensaio de anti-tTG IgA permite um intervalo de leitura de no mínimo 1,9 CU até no máximo $4.956 \mathrm{CU}$, a partir dessa concentração, a amostra deverá submeter-se a uma diluição para a mensuração real do anticorpo anti-tTG IgA.

De acordo com os valores de referência do fabricante e a análise estatística da Receiver Operating Characteristic (Curva ROC), as amostras com resultados abaixo de 30 CU foram consideradas negativas e resultados acima de $30 \mathrm{CU}$ consideradas positivas.

\subsection{Procedimento analítico}

As 11 amostras de pacientes previamente diagnosticados como doentes celíacos, foram submetidos à dosagem de anti-tTG por ELISA e logo após a análise, foram armazenadas a temperatura de $-20^{\circ} \mathrm{C}$ em tubos tipo eppendorf.

Após 7 dias corridos, as 11 amostras armazenadas a $-20^{\circ} \mathrm{C}$, foram descongeladas até atingirem a temperatura ambiente - sem indução térmica (banho maria) ou mecânica (homogeneização) - de 18 a $23^{\circ}$ C. Depois do descongelamento, as amostras foram homogeneizadas por inversão lenta e inseridas no equipamento para dosagem de antitransglutaminase IgA por quimioluminescência. Paralelamente a essas análises, foram dosadas 171 amostras com resultados negativos na metodologia de ELISA. Essas amostras com resultados negativos foram analisadas por quimioluminescência imediatamente após a liberação das amostras pelo sistema automatizado Best $2000 \circledR$, não sendo submetidas ao processo de congelamento e descongelamento de amostras.

Nesse estudo, após mensurar ambas as metodologias, ELISA e quimioluminescência para anti-tTG IgA, foi utilizada a curva ROC para obter o ponto de corte e determinar a sensibilidade e especificidade dos ensaios.

Para definir os parâmetros de validação do ensaio, foi utilizada a combinação binária (Quadro 2), relacionando os resultados obtidos pelo método referência (ELISA) e os resultados obtidos do método em validação (quimioluminescência). 
Quadro 2 - Combinação binária (matriz de contingência 2x2) entre o método referência (ELISA) e o método em validação (quimioluminescência).

\begin{tabular}{|c|c|c|}
\hline Método em validação & \multicolumn{2}{|c|}{ Método referência (ELISA) } \\
\hline (Quimioluminescência) & Positivos & Negativos \\
\hline Positivos & VP -Verdadeiros positivos (a) & FP - Falsos positivos (b) \\
\hline Negativos & FN - Falsos negativos (c) & VN - Verdadeiros negativos (d) \\
\hline Total & $a+c$ & $b+d$ \\
\hline
\end{tabular}

\subsubsection{Parâmetros extrínsecos}

A análise dos parâmetros extrínsecos retrata o desempenho analítico da metodologia que está em processo de validação. Esse desempenho analítico está relacionado com a medição de reprodutibilidade, exatidão, precisão e grau de concordância dos resultados comparados à referência.

\subsubsection{1. Índice Kappa $(\kappa)$}

Para avaliarmos o índice de concordância entre os métodos ELISA e Quimioluminescência empregados, calculamos o índice Kappa (K),

Após a quantificação do anticorpo nas amostras por ELISA e quimioluminescência, os resultados foram anotados e avaliados individualmente. Para a construção da combinação binária, bem como o cálculo do índice Kappa, a metodologia de ELISA foi utilizada como referência para classificar as amostras como verdadeiras positivas e verdadeiras negativas; e, os resultados discordantes obtidos pela quimioluminescência quando comparados aos de ELISA, foram classificados como falso positivos e falsos negativos.

O índice kappa foi calculado da seguinte maneira:

$$
\begin{gathered}
P o=\frac{a+d}{n} \\
P e=\frac{[(a+b)(a+c)]+[(c+d)(b+d)]}{n^{2}} \\
\kappa=\frac{P o-P e}{1-P e}
\end{gathered}
$$


Onde:

$\mathrm{a}=$ verdadeiros positivos

$\mathrm{b}=$ falsos positivos

$\mathrm{c}=$ falsos negativos

$\mathrm{d}=$ verdadeiros negativos

Po $=$ concordâncias observadas

$\mathrm{Pe}=$ concordâncias esperadas

$\mathrm{K}=$ índice Kappa

$\mathrm{n}=$ número total de amostras

\subsubsection{Precisão Intraensaio}

A precisão intraensaio foi realizada de acordo com as recomendações EP5-A2 do Clinical and Laboratory Standards Institute (CLSI). Para análise dos dados foi calculado o Coeficiente de Variação (CV \%) das dosagens realizadas em cada controle, esse cálculo tem a finalidade de analisar a homogeneidade dos resultados obtidos, ou seja, a reprodutibilidade dos resultados. Quanto menor é o CV \% mais homogêneos ou reprodutivos são os resultados, $\mathrm{CV} \%<15 \%$ representa alta homogeneidade ou reprodutibilidade, CV\% entre $15-30 \%$ representa média homogeneidade entre os resultados e valores $>30 \%$ baixa homogeneidade entre os resultados ou baixa reprodutibilidade. Para calcular o CV \% empregamos a fórmula CV $=$ DP/X x 100, onde DP é o desvio-padrão, e X é a média encontrada nas dosagens dos controles.

Esse valor foi considerando a variação máxima de discordância permitida entre os valores medidos. Para essa análise de precisão, foram realizadas 20 medições na mesma amostra medidos repetidamente e simultaneamente (COMMISSION, 2007).

Utilizamos uma amostra de controle negativo e uma de controle positivo, ambos pertencentes ao mesmo lote (Lote 151019) e específicos para o equipamento de quimioluminescência. Cada controle contém quantidades diferentes de anticorpos IgA anti-htTG, o controle baixo foi descrito pelo fabricante com limites aceitáveis de 5,6 a 13 CU, e o controle alto 33,2 a $77,6 \mathrm{CU}$.

Os controles foram armazenados sob refrigeração em temperatura controlada de 2 a $8^{\circ}$ C. O fabricante recomenda a dosagem imediata após retirar da refrigeração, sem a necessidade de aguardar que atinjam temperatura ambiente $25^{\circ} \mathrm{C}$ para serem analisados.

Antes de retirar os controles da refrigeração para realização das dosagens, o cadastro foi realizado no software do equipamento Bio-Flash ${ }$, informando as concentrações conhecidas dos controles (Lote 151019), bem como sua data de validade e limites aceitáveis de resultados de acordo com o desvio padrão sugerido na bula do fabricante (Tabela 1). 
Após o cadastro no sistema analítico, os controles foram inseridos no equipamento e em cada um foi mensurado o anticorpo anti-transglutaminase $\operatorname{Ig}$ A por quimioluminescência.

\subsubsection{Precisão Interensaio}

A precisão interensaio foi realizada de acordo com as recomendações EP5-A2 do Clinical and Laboratory Standards Institute (CLSI). Para análise dos dados foi calculado o Coeficiente de Variação (CV \%) das dosagens realizadas em cada controle, esse cálculo tem a finalidade de analisar a homogeneidade dos resultados obtidos, ou seja, a reprodutibilidade dos resultados. Quanto menor é o CV \% mais homogêneos ou reprodutivos são os resultados, $\mathrm{CV} \%<15 \%$ representa alta homogeneidade ou reprodutibilidade, CV\% entre $15-30 \%$ representa média homogeneidade entre os resultados e valores $>30 \%$ baixa homogeneidade entre os resultados ou baixa reprodutibilidade. Para calcular o CV \% empregamos a fórmula $\mathrm{CV}=\mathrm{DP} / \mathrm{X}$ x 100, onde DP é o desvio-padrão, e X é a média encontrada nas dosagens dos controles.

Esse valor foi considerando a variação máxima de discordância permitida entre os valores medidos. Para essa análise, foram realizadas quatro réplicas em cinco dias alternados na mesma amostra, medidos repetidamente e simultaneamente (COMMISSION, 2007).

Para esse ensaio, utilizou-se uma amostra de controle negativo e uma de controle positivo, ambos pertencentes ao mesmo lote (Lote 151019) e específicos para o equipamento de quimioluminescência. Cada controle contém quantidades diferentes de anticorpos IgA anti-h-tTG, o controle baixo foi descrito pelo fabricante com limites aceitáveis de 5,6 a 13 CU, e o controle alto 33,2 a 77,6 CU. Os valores preconizados pelo fabricante encontram-se dispostos na Tabela 1 .

Tabela 1 - Valores esperados para os controles, fornecidos pelo fabricante.

\begin{tabular}{lcccc}
\hline Controle & Nome & Média $(\mathbf{C U})$ & DP & $\begin{array}{c}\text { Intervalo } \\
\text { aceitável }(\mathbf{C U})\end{array}$ \\
\hline Negativo & TTGAN & 9,3 & 1,24 & 5,6 a 13,0 \\
\hline Positivo & TTGAP & 55,4 & 7,37 & 33,2 a 77,6 \\
\hline
\end{tabular}




\subsubsection{Parâmetros intrínsecos}

A avaliação dos parâmetros intrínsecos ilustra o desempenho do analito quando comparado ao método referência e a eficácia diagnóstica.

\subsubsection{Curva Receiver Operating Characteristic (Curva ROC)}

Após avaliar as amostras pelo ponto de corte obtido, foi elaborada a curva ROC, para que os parâmetros da área sob a curva pudessem ser analisados com a finalidade de validar o ensaio de quimioluminescência, a fim de averiguar se a acurácia dessa metodologia é comparável à metodologia de ELISA (método referência). Os resultados do ensaio de anti-tTG IgA foram plotados e calculados pelo programa Graphpad Prism versão 6.0101 (GraphPad Software, San Diego, Califórnia, USA).

Para a elaboração do eixo $\mathrm{x}$ da curva ROC, foram selecionadas todas as com probabilidade de resultados falso positivos e para compor o eixo y, todas as amostras com probabilidade de verdadeiro positivo. A partir disto, eixo x (1-especificidade) e eixo y (sensibilidade), foram empregados para calcular a área sob a curva com o objetivo de analisar o desempenho do método, interpretando a probabilidade do indivíduo portador de doença ter o resultado do teste diagnóstico de maior magnitude do que aquele indivíduo que não porta a doença. Um teste totalmente incapaz de discriminar os indivíduos doentes dos não doentes, teriam uma área sob a curva de 0,5. Portanto, quanto maior a capacidade do teste em discriminar os indivíduos, segundo esses dois grupos, a curva se aproximaria do canto superior esquerdo do gráfico, e a área sob a curva mais próxima de 1.

\subsubsection{Sensibilidade}

Baseado no quadro de combinação binária, foi usada a seguinte fórmula para calcular a sensibilidade da quimioluminescência:

$$
\text { Sensibilidade }=\frac{a}{(a+c)}
$$

Onde:

$\mathrm{a}=$ verdadeiros positivos

$\mathrm{c}=$ falsos negativos 


\subsubsection{Especificidade}

Baseado no quadro de combinação binária, foi usada a seguinte fórmula para calcular a especificidade da quimioluminescência:

$$
\text { Especificidade }=\frac{d}{(b+d)}
$$

Onde:

$\mathrm{d}=$ verdadeiros negativos

$\mathrm{b}=$ falsos positivos

\subsubsection{Acurácia}

Baseado no quadro de combinação binária, foi usada a seguinte fórmula para calcular a eficiência da quimioluminescência:

Onde:

$$
\text { Acurácia }=\frac{a+d}{n}
$$

$\mathrm{a}=$ verdadeiros positivos

$\mathrm{d}=$ verdadeiros negativos

$\mathrm{n}=$ número total de amostras do estudo

\subsubsection{Parâmetros que dependem da prevalência da doença}

\subsubsection{Valor preditivo positivo (VPP)}

Baseado no quadro de combinação binária, foi usada a seguinte fórmula para calcular a porcentagem do VPP na quimioluminescência:

$$
V P P=\frac{a}{(a+b)}
$$

Onde:

$\mathrm{a}=$ verdadeiros positivos

$\mathrm{b}=$ falsos positivos 


\subsubsection{Valor preditivo negativo (VPN)}

Baseado no quadro de combinação binária, foi usada a seguinte fórmula para calcular a porcentagem do VPN na quimioluminescência:

$$
V P N=\frac{d}{(c+d)}
$$

Onde:

$\mathrm{d}=$ verdadeiros negativos

$\mathrm{c}=$ falsos negativos

\subsubsection{Razão de verossimilhança positiva (RVP)}

Baseado no quadro de combinação binária, foi usada a seguinte fórmula para calcular a RVP na quimioluminescência:

$$
R V P=\frac{\frac{a}{a+c}}{\frac{b}{b+d}}
$$

Onde:

$\mathrm{a}=$ verdadeiros positivos

$\mathrm{b}=$ falsos positivos

$\mathrm{c}=$ falsos negativos

$\mathrm{d}=$ verdadeiros negativos

A RVP pode ser reescrita dessa forma:

$$
R V P=\frac{\text { Sensibildiade }}{1-\text { Especificidade }}
$$

\subsubsection{Razão de verossimilhança negativa $(R V N)$}

Baseado no quadro de combinação binária, foi usada a seguinte fórmula para calcular a RVN na quimioluminescência:

$$
R V N=\frac{\frac{c}{a+c}}{\frac{d}{b+d}}
$$


Onde:

$\mathrm{a}=$ verdadeiros positivos

$\mathrm{b}=$ falsos positivos

$\mathrm{c}=$ falsos negativos

$\mathrm{d}=$ verdadeiros negativos

A RVN pode ser reescrita dessa forma:

$$
R V N=\frac{1-\text { Sensibildiade }}{\text { Especificidade }}
$$

\subsection{Análise estatística}

Para a análise estatística do desempenho analítico das metodologias desse estudo, foram utilizados os softwares GraphPad Prism versão 6.01 (GraphPad Software, San Diego, Califórnia, USA) e MedCal Software bvba versão 16.4 (Copyright $@$, Acacialaan, Ostend, Bélgica). 


\section{RESULTADOS}

Após as análises de anticorpos anti-transglutaminase da classe IgA (tTG IgA) pela técnica de ELISA, 11 (6\%) amostras apresentaram resultados positivos tTG IgA (Cut-off acima de $30 \mathrm{U}$ ) e 171 (94\%) amostras com resultados negativos (Cut-off abaixo de $29 \mathrm{U}$ ), de um total de 182 amostras. Pela técnica de imunofluorescência $13(7,2 \%)$ destas amostras apresentaram resultados positivos (Cut-off acima de 30 U) e 169 (92,8 \%) amostras apresentaram resultados negativos (Cut-off abaixo de $29 \mathrm{U}$ ).

\subsection{Parâmetros extrínsecos}

\subsection{1. Índice Kappa}

O índice Kappa (k) obtido foi de 0,732 (IC 0,528 a 0,937, Erro padrão 0,104), o número de concordância esperado seria 156,6 amostras $(87,68 \%)$ e o número real de concordância das amostras obtido foi de $176(96,70$ \%). Estes resultados nos permitem inferir que o grau de concordância entre os métodos de ELISA e Quimioluminescência é classificado como "substancialmente concordante" porque o índice Kappa está no intervalo 0,610 - 0,800 da escala de classificação deste índice, um nível abaixo da classificação máxima de concordância (Graphpad, 2016).

\subsubsection{Precisão intraensaio}

Considerando o CV \% encontrado após as análises intraensaio de 4,4\% e 3,4\%, respectivamente para o controle negativo e o positivo, podemos afirmar que esses resultados observados nos controles são homogêneos, de alta reprodutibilidade e precisão, porque os valores de CV\% encontrados são inferiores a 10\%. Comparando o CV\% do fabricante com nossos resultados observamos um discreto aumento do $\mathrm{CV} \%$, o que não é representativo de para análise precisão do ensaio (Tabela 2). 
Tabela 2 - Resultados de precisão intraensaio.

\begin{tabular}{lccccc}
\hline & $\begin{array}{c}\text { Limites aceitáveis } \\
(\mathbf{C U})\end{array}$ & $\begin{array}{c}\text { Média } \mathbf{F} \\
(\mathbf{C U})\end{array}$ & $\begin{array}{c}\text { Média } \mathbf{C} \\
(\mathbf{C U})\end{array}$ & $\begin{array}{c}\text { CVF } \\
(\boldsymbol{\%})\end{array}$ & $\begin{array}{c}\text { CVO } \\
(\%)\end{array}$ \\
\hline $\begin{array}{l}\text { Controle } \\
\text { Negativo }\end{array}$ & $5,6-13$ & $8,7 \pm 0,3$ & $9,1 \pm 0,4$ & 3,4 & 4,4 \\
\hline $\begin{array}{l}\text { Controle } \\
\text { Positivo }\end{array}$ & $33,2-77,6$ & $40,5 \pm 1,2$ & $52,9 \pm 1,8$ & 2,9 & 3,4 \\
\hline
\end{tabular}

Média $\mathrm{F}$ - média fornecida pelo fabricante, Média $\mathrm{O}$ - média dos valores observados, DPF e DPO - desviopadrão Fabricante e Observado, CVF e CVO - Coeficiente de Variação Fabricante e observado.

\subsubsection{Precisão Interensaio}

Foram realizadas 4 réplicas simultâneas em cinco dias consecutivos para avaliar a precisão de acordo com o recomendado pelo fabricante. Os resultados são representados nas Tabelas 3 e 4.

Para a análise dos dados foram calculados a Média, Desvio Padrão (DP) e Coeficiente de Variação (CV\%) das dosagens realizadas em cada controle. Foi realizado o cálculo de Média aritmética simples para obtenção de uma concentração única a partir de vários resultados, esse cálculo tem a finalidade de comparar com os valores conhecidos fornecidos pelo fabricante, a fim de analisar se essa média observada se encontra dentro do intervalo aceitável para o controle, fornecido pelo fabricante. A média também foi empregada para outros cálculos, como Desvio Padrão e Coeficiente de Variação, que foram calculados para as dosagens realizadas em cada controle, esse cálculo tem a finalidade de analisar a homogeneidade dos resultados obtidos, ou seja, a reprodutibilidade dos resultados.

$\mathrm{Na}$ análise interensaio, além de avaliar a reprodutibilidade, conforme descrito anteriormente os resultados foram analisados de acordo com o intervalo aceitável dos controles. Considerando o intervalo aceitável para o controle negativo de 5,6 a 13,0 CU e que as médias nos 5 dias analisados foram 8,$8 ; 9,5 ; 9,1 ; 9,2$ e 8,8, podemos afirmar que esses resultados observados para o controle negativo se encontram dentro do intervalo aceitável, com valores muito próximos da média para esse controle, que é de 9,3 CU. Além disso, foi possível observar que, os DPs nos dias das análises são todos inferiores ao fornecido pelo fabricante, demonstrando que os resultados encontram-se dispostos bem próximos da média. Quanto ao CV\%, os resultados demonstram que são homogêneos, de alta reprodutibilidade e precisão, porque os valores de CV \% encontrados são inferiores a 10\%. Ao comparar o CV\% 
médio do fabricante $(3,4 \%)$ com a média dos nossos resultados de CV \% $(3,94 \%)$ observamos um discreto aumento do $\mathrm{CV} \%$, o que não é representativo para análise precisão do ensaio (Tabela 3).

Tabela 3 - Resultados de controle negativo, precisão interensaio

\begin{tabular}{lccccc}
\hline Controle Negativo & Dia 1 & Dia 2 & Dia 3 & Dia 4 & Dia 5 \\
\hline Réplica 1 & 8,9 & 9,2 & 9,7 & 9,2 & 8,7 \\
\hline Réplica 2 & 9,1 & 9,4 & 8,7 & 8,6 & 8,7 \\
\hline Réplica 3 & 8,3 & 9,7 & 8,7 & 9,5 & 9,2 \\
\hline Réplica 4 & 9,0 & 9,7 & 9,2 & 9,5 & 8,6 \\
\hline Média & 8,8 & 9,5 & 9,1 & 9,2 & 8,8 \\
\hline DP & 0,4 & 0,2 & 0,5 & 0,4 & 0,3 \\
\hline CV\% & 4,1 & 2,6 & 5,3 & 4,6 & 3,1 \\
\hline
\end{tabular}

Considerando o intervalo aceitável para o controle positivo de 33,2 a 77,6 CU e que as médias nos 5 dias analisados foram 53,$5 ; 52 ; 53,5 ; 53,9$ e 52,8 , podemos afirmar que esses resultados observados para o controle positivo se encontram dentro do intervalo aceitável, com valores muito próximos da média para esse controle, que é de 55,4 CU. Além disso, é possível observar que, os DPs observados nos dias das análises são todos inferiores ao fornecido pelo fabricante, demonstrando que os resultados encontram-se dispostos bem próximos da média. Quanto ao CV\%, os resultados demonstram que são homogêneos, de alta reprodutibilidade e precisão, porque os valores de $\mathrm{CV} \%$ encontrados são inferiores a $10 \%$. Ao comparar o CV\% do fabricante $(2,9 \%)$ com o CV \% médio dos nossos resultados $(2,72 \%)$ observamos a precisão do controle positivo (Tabela 4).

Tabela 4 - Resultados de controle positivo, precisão interensaio.

\begin{tabular}{llllll}
\hline Controle Positivo & Dia 1 & Dia 2 & Dia 3 & Dia 4 & Dia 5 \\
\hline Réplica 1 & 52,1 & 52,3 & 52,6 & 52,4 & 50,7 \\
\hline Réplica 2 & 53,8 & 52,1 & 54,2 & 53,1 & 51,9 \\
\hline Réplica 3 & 56,2 & 52,5 & 53,1 & 56 & 52,4 \\
\hline Réplica 4 & 51,8 & 51,1 & 54,0 & 52,4 & 56 \\
\hline Media & 53,5 & 52,0 & 53,5 & 53,9 & 52,8 \\
\hline SD & 2,0 & 0,6 & 0,8 & 1,6 & 2,3 \\
\hline CV\% & 3,8 & 1,2 & 1,4 & 2,9 & 4,3 \\
\hline
\end{tabular}




\subsection{Parâmetros intrínsecos e parâmetros que dependem da prevalência da doença}

\subsubsection{Parâmetros intrínsecos}

\subsubsection{Curva Receiver Operating Characteristic (Curva ROC)}

Após a análise dos resultados obtidos entre as duas metodologias, btivemos a seguinte curva ROC, disposta na Figura 7, para a validação do método de quimioluminescência, utilizando ELISA como método referência.

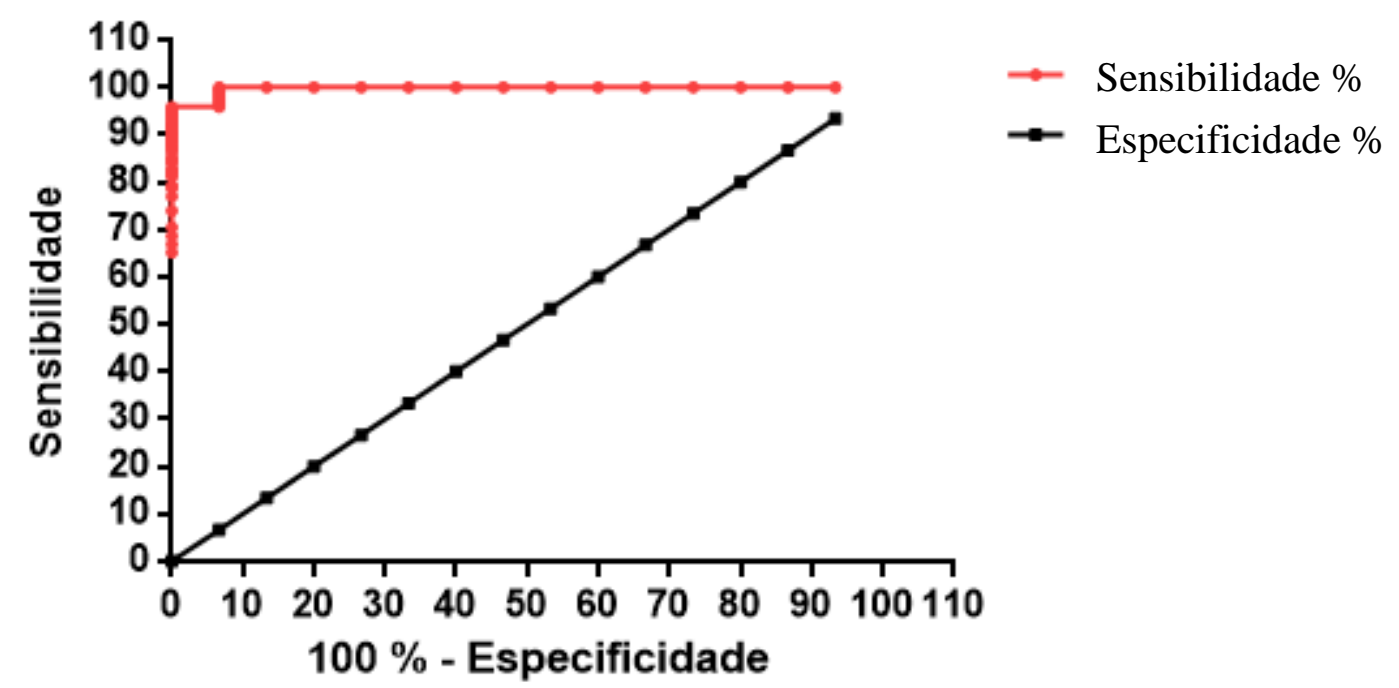

Figura 7 - Curva ROC (Receiver Operating Characteristics). Desempenho do ensaio Anti-tTG IgA por quimioluminescência (linha vermelha), acurácia de 50\% (linha preta)

A área sob a curva encontrada foi de 0,9972 $\pm 0,0030$ (IC 95\%: 0,9913 a 1,003), e a diferença entre as metodologias foi estatisticamente significante $(p<0,0001)$. Levando em consideração esses resultados, pode-se afirmar que o ensaio de quimioluminescência possui grande capacidade de discriminatória entre indivíduos doentes e não doentes comparando-se com a metodologia referência (ELISA).

\subsubsection{Sensibilidade, Especificidade e Acurácia}

Os resultados obtidos das análises por ELISA e por quimioluminescência foram plotados na matriz de contingência $2 \times 2$, levando em consideração como método referência, o ELISA e método em validação, a quimioluminescência. Os resultados positivos e negativos foram determinados por meio do cut off (ponto de corte) preestabelecido e classificados como: 
a- verdadeiros positivos (VP), selecionandas as amostras positivas no ELISA e positivas na quimioluminescência; b- falso positivo (FP), resultados negativos no ELISA e positivos na quimioluminescência; c- falso negativo (FN), resultados positivos no ELISA e negativos na quimioluminescência; d- verdadeiro negativo (VN), negativos no ELISA e negativos na quimioluminescência.

Os resultados das 182 amostras analisadas foram dispostos conforme o Quadro 3.

Quadro 3 - Combinação binária (matriz de contingência 2x2) entre o método referência (ELISA) e o método em validação (quimioluminescência).

\begin{tabular}{|l|c|c|}
\hline $\begin{array}{l}\text { Método em validação } \\
\text { (Quimioluminescência) }\end{array}$ & \multicolumn{2}{|c|}{ Método referência (ELISA) } \\
Positivos & $\mathrm{VP}=9(\mathrm{a})$ & Negativos \\
\hline Negativos & $\mathrm{FN}=2(\mathrm{c})$ & $\mathrm{FP}=4(\mathrm{~b})$ \\
\hline Total & $\mathrm{a}+\mathrm{c}=11$ & $\mathrm{VN}=167(\mathrm{~d})$ \\
\hline
\end{tabular}

Os ensaios de quimioluminescência e ELISA foram comparados usando o método de combinação binária 2x2, utilizando o GraphPad Prism 6.0, para realizar os cálculos, foram obtidos os coeficientes de concordância, aos quais obtivemos os seguintes resultados e os intervalos de confiança (IC) conforme apresentados na Tabela 5.

Os cálculos revelaram para a metodologia de quimioluminescência apresentou 81,8\% de sensibilidade e $97,6 \%$ de especificidade em relação ao método referência (que apresenta segundo a referência técnica do fabricante, sensibilidade de 92,7\% e especificidade de 91,6\%), o que sugere que a metodologia de quimioluminescência é mais específica do que sensível, ou seja, apresenta maior capacidade de detectar indivíduos verdadeiramente negativos e que apresenta melhor especificidade que o método referência. $\mathrm{O}$ ensaio também apresentou eficiência de 0,94 ou $94 \%$, quanto mais próximo de 1 ou $100 \%$ melhor é o teste avaliado, o que nos permite afirmar que a eficiência do ensaio de quimioluminescência é excelente, está muito próxima do máximo (Tabela 5). 
Tabela 5 - Parâmetros intrínsecos calculados para a metodologia de quimioluminescência tendo a metodologia ELISA como método referência.

\begin{tabular}{lc}
\hline Parâmetros Intrínsecos & IgA tTG \\
\hline Ponto de corte (cut off) & 30 CU \\
\hline Sensibilidade - S \% (IC 95 \%) & $81,8 \%$ \\
& $(48,2-97,7)$ \\
\hline Especificidade - E \% (IC 95 \%) & $97,6 \%$ \\
\hline Eficiência ou Acurácia (\%) & $(94,1-99,3)$ \\
\hline
\end{tabular}

\subsubsection{Parâmetros que dependem da prevalência da doença}

Em relação ao Valor Preditivo Positivo (VPP \%), que permite avaliar a probabilidade de doença quando o resultado do ensaio é positivo, obtivemos um valor de 69,2\%, o que sugere que um indivíduo com resultado positivo de Transglutaminase IgA (tTG IgA) tem 69,2\% de chance de desenvolvimento de Doença Celíaca (DC). Já em relação ao Valor Preditivo Negativo (VPN \%), que avalia probabilidade de não ocorrência da doença quando o resultado do ensaio é negativo, obtivemos $98,8 \%$, que infere que um resultado de tTG IgA negativo tem 98,8 \% de chance de não desenvolvimento da DC (Tabela 6).

Analisando a Razão de Verossimilhança (RV) que descreve o desempenho de um teste diagnóstico utilizando o mesmo tipo de informação que a sensibilidade/especificidade, e permite calcular a probabilidade de doença depois de um teste positivo (RVP \%) ou negativo (RVN \%), podemos afirmar que a metodologia de quimioluminescência apresenta excelente desempenho analítico com RV de 34,98 (Tabela 6).

Em relação à Razão de Verossimilhança Positiva (RVP \%), que avalia a probabilidade de esperar um resultado positivo para um indivíduo doente e a probabilidade do mesmo resultado em um indivíduo não portador da doença, quanto maior a RVP \%, melhor é o teste utilizado para o diagnóstico, neste caso obtivemos uma RVP de 27, que indica bom desempenho analítico do ensaio quimioluminescentes para distinguir testes positivos e negativos. Já para a Razão de Verossimilhança Negativa (RVN \%), que calcula a probabilidade do resultado esperado para um indivíduo sadio e a probabilidade do mesmo resultado em um indivíduo portador da doença, neste caso quanto menor o RVN melhor é a capacidade do método de discernir entre indivíduos negativos e positivos, aqui o valor 
encontrado foi de 0,19 , considerado muito baixo, o que demostra que o ensaio quimioluminescentes apresentou essa capacidade (Tabela 6).

Quando analisamos o Risco Relativo (RR) que avalia o risco ou probabilidade de desenvolver neste caso Doença Celíaca (DC), encontramos um RR de 58,5 ( $p<0,001)$, que significa que, a presença de um resultado tTG IgA positivo é um fator predisponente para o desenvolvimento de DC, e representa um risco de 58,5 vezes (Tabela 6) maior nestes indivíduos do que naqueles que não apresentam positividade no teste.

E finalmente, a análise de Odds ratio $(O D)$ ou razão de chances, que permite avaliar se há associação entre a presença de tTG IgA e a chance de desenvolvimento da DC. Neste caso o OD é avaliado como OD $<1$ (associação protetora), $\mathrm{OD}=1$ (não há associação entre as variáveis estudadas) e OD > 1 (há associação entre as variáveis estudadas e quanto maior o número obtido acima de 1 , mais forte a associação). O OD obtido foi de 187,9 , que representa forte associação, ou seja, os indivíduos que apresentam tTG IgA positivo têm 187,9 vezes (Tabela 6) mais chance ou possibilidade de desenvolver DC.

Tabela 6 - Parâmetros que dependem da prevalência da doença calculados para a metodologia de quimioluminescência tendo a metodologia ELISA como método referência.

\begin{tabular}{lc}
\hline Parâmetros associados à Prevalência da Doença & IgA tTG \\
\hline Valor Preditivo Positivo - VPP \% (IC 95 \%) & $69,2 \%$ \\
& $(38,6-90,9)$ \\
\hline Valor Preditivo Negativo - VPN \% (IC 95 \%) & $98,8 \%$
\end{tabular}

$(95,7-99,8)$

\begin{tabular}{lc}
\hline Razão de Verossimilhança (RV) (likelihood ratio) & 34,98 \\
\hline Razão de Verossimilhança Positiva - RVP \% (IC 95 \%) & 27 \\
\hline Razão de Verossimilhança Negativa - RVN \% (IC 95 \%) & 0,19 \\
\hline Risco Relativo (RR) (IC 95 \%) & 58,5 \\
\hline Odds Ratio (IC 95 \%) & $(14,07$ a 243,2) \\
\hline
\end{tabular}

CU - unidades quimioluminescente, IC - intervalo de confiança, S - sensibilidade, E - especificidade, VPP valor preditivo positivo, VPN - valor preditivo negativo, RVP - razão de verossimilhança positivo, RVN - razão de verossimilhança negativo 


\section{DISCUSSÃO}

A dosagem de anticorpos anti-transglutaminase classe IgA (tTG IgA) é a primeira escolha diagnóstica em pacientes com sintomas suspeitos de doença celíaca (HILL, 2005; HUSBY, 2012) e em 2012, a ESPGHAN revisou seus critérios diagnósticos que contribuíram para que o teste sorológico ganhasse ainda mais relevância. Desde então, pacientes com suspeita de DC que apresentam tTG IgA cerca de 10 vezes o valor do cut-off do kit diagnóstico, com anti-endomísio IgA positivo, e a presença de genes HLA-DQ2 ou HLADQ8 confirmada por genotipagem, podem ter o diagnóstico de Doença Celíaca confirmada, sem a necessidade de realização de biópsia (HUSBY, 2012).

A maioria dos ensaios comercialmente disponíveis para a detecção de tTG são testes baseados em ELISA (AITA et al., 2013), que produzem resultados confiáveis com boa sensibilidade e especificidade, estes dados podem ser suportados por estudos de metaanálises, dentre estes um dos primeiros estudos realizados apontaram sensibilidade e especificidade de tTG IgA mais elevados do que $92 \%$ e 96\%, respectivamente (ZINTZARAS et al., 2006).

Recentemente, além do ELISA há disponibilidade de outras metodologias para a dosagem de tTG IgA, como por exemplo, Enzimaimunoensaio Fluorimétrico (FEIA) e Imunoensaios por Quimioluminescência. Estas metodologias já realizadas em analisadores totalmente automatizados, têm melhorado a precisão dos resultados, o que promove uma alta eficiência diagnóstica com o uso destes imunoensaios (RESS et al., 2011; AITA et al., 2013), razão pela qual este estudo propõe uma avaliação analítica de um ensaio de quimioluminescência em equipamento automatizado.

Para além da vantagem de realizar o teste de forma automatizada, a metodologia de quimioluminescência apresenta ainda algumas vantagens superiores ao ELISA, tais como: alta sensibilidade e especificidade, limites de detecção mais abrangentes, nítida distinção entre resultados positivos e negativos, processamento das análises de forma mais rápida, e simplicidade de processamento atrelada à automação, o que torna essa metodologia mais atrativa como ferramenta diagnóstica (BAEYENS et al., 1998; BASSO et al., 2006; AITA et al. 2013; MAHLER et al., 2016).

Para melhor compreensão da avaliação das duas metodologias estudadas, os resultados foram divididos em duas fases. A primeira avaliou a Performance Analítica do método, onde foram calculados Índice Kappa, sensibilidade, especificidade e exatidão, os chamados 
parâmetros extrínsecos: ensaios de precisão intraensaio (precisão) e precisão interensaio (exatidão). E a segunda fase para avaliação da Performance Clínica do método, onde foram calculados Valor Preditivo Positivo e Negativo, Razão de Verossimilhança Positiva e Negativa, Risco Relativo e Odds Ratio, os chamados parâmetros intrínsecos e que dependem da prevalência da doença, além da Curva ROC.

Na primeira fase de Performance analítica, ao analisarmos os resultados da precisão intraensaio obtidos na quimioluminescência a partir do controle negativo e positivo, obtivemos alta precisão, pois o coeficiente de variação observado foi inferior a 4,4 \%. Dados semelhantes foram constatados no estudo realizado por Aita e colaboradores (2013), que observaram um coeficiente de variação inferior a $4 \%$. A importância de realizar a avaliação da precisão intraensaio, permite constatar a eficácia das análises, garantindo a repetitividade, favorecendo testes acurados com o máximo de precisão, o que nos permite inferir que os resultados obtidos nesse estudo e no método de quimioluminescência empregados são precisos.

Ainda nesta etapa, quando analisamos a precisão interensaio obtida na quimioluminescência, foi constatada excelente exatidão, pois o desvio padrão observado foi de 0,37 para o controle baixo, e de 1,46 para o controle alto, comparado aos dados fornecidos pelo fabricante, que forneceu o desvio padrão para o controle baixo de 1,24 e para o controle alto 7,37. A importância de avaliar a precisão interensaio, permitiu constatar a exatidão do ensaio, ou seja, garantir o resultado verdadeiro para o teste em análise, pois quanto mais baixo o desvio padrão, mais próximo o resultado está da concentração real.

Além destas análises, calculamos o Índice Kappa (k), que permite avaliar a concordância entre os métodos avaliados, neste caso ELISA e quimioluminescência. A concordância observada foi de $96,7 \%$ com $\mathrm{k}=0,732$, o que o classifica como substancialmente concordante, na escala de classificação deste índice. Diante destes dados, podemos inferir que os resultados obtidos em ambos os métodos, referência e quimioluminescência apresentam confiabilidade.

$\mathrm{Na}$ segunda fase, a da Performance Clínica, iniciamos as análises dos parâmetros intrínsecos, sensibilidade, especificidade e exatidão. Ao comparar duas metodologias, é de grande importância analisar a sensibilidade e especificidade analítica de cada uma individualmente. O objetivo dessas análises é garantir que os resultados verdadeiramente positivos e verdadeiramente negativos serão identificados, assim é possível diagnosticar os doentes e os não doentes. De um modo geral, quanto mais o ensaio ganhar em sensibilidade, 
mais perderá em especificidade e vice-versa. $\mathrm{O}$ ensaio ideal é aquele que consiga manter tanto a sensibilidade quanto a especificidade o mais próximo de $100 \%$, para que as análises possam ter o menor índice de resultados falso negativos (alta especificidade) ou falso positivos (alta sensibilidade).

Ao compararmos nossos dados com outros estudos, encontramos apenas um estudo publicado na literatura com os mesmos kits diagnósticos que utilizamos. Neste estudo realizados por Aita e colaboradores (2013) e considerando os dados fornecidos pelo fabricante (INOVA), os dados encontrados de sensibilidade analítica foram de 90,5\% e 92,3\%, respectivamente. Quando comparamos aos dados obtidos em nosso estudo encontramos uma sensibilidade de $81,8 \%$. Essa diferença observada, provavelmente tem relação direta com o cut-off. Outros autores já chamaram atenção para o fato de que os pontos de corte ou cut-off, que diferem para cada método e de um teste comercial para outro, resultam em variação na precisão e consequentemente no diagnóstico (VERMEERSCH et al., 2013).

Quando avaliamos o ponto de corte ou cut-off do ensaio quimioluminescente, Aita e colaboradores (2013) consideraram um cut-off de 16 CU, o fabricante INOVA considera um cut-off de $20 \mathrm{CU}$ e nesse estudo, após análise da curva ROC, consideramos um cut-off de 30 $\mathrm{CU}$, o que explicaria uma menor sensibilidade do método para as amostras estudadas.

Fazendo uma reflexão mais profunda sobre a sensibilidade analítica encontrada 90,5\% (AITA et al., 2013) e 92,3\% (fabricante), e com os valores de cut-off de $16 \mathrm{CU}$ e $20 \mathrm{CU}$, respectivamente, e comparando com os nossos dados sensibilidade de 81,8\% e cut-off de 30 $\mathrm{CU}$, poderíamos sugerir que quanto menor o cut-off maior a sensibilidade analítica encontrada, mas essa sentença não é verdadeira quando analisamos os dados de Aita e colaboradores (2013), pois embora seu cut-off tenha sido inferior ao do fabricante, sua sensibilidade analítica não foi mais elevada que a encontrada pelo fabricante, o que nos leva a refletir que outros fatores, tais como: equipamento, calibração, condições de temperatura do ambiente, ajustes de instalação, também possam ainda que minimamente interferir na sensibilidade analítica, ou um destes dados estão inconsistentes.

Avaliando agora os nossos dados, como o cut-off empregado em nosso estudo foi maior que o do estudo de Aita e colaboradores (2013), seguindo o mesmo raciocínio, era de se esperar que a nossa sensibilidade analítica fosse menor que a encontrada no estudo deles, embora empregando o mesmo kit diagnóstico e equipamento, e de fato estes dados encontrados concordam com a hipótese, o que aparentemente reforça a ideia de inconsistência em um dos dados. 
Analisando agora os demais parâmetros da segunda fase, a da Performance Clínica, que dependem da prevalência da doença. O Valor Preditivo Positivo (VPP \%) do estudo realizado por Aita e colaboradores (2013) e os fornecidos pelo fabricante (INOVA) foram respectivamente de $96,8 \%$ e $100 \%$ respectivamente, e os dados encontrados nesse estudo, revelaram um VPP de 69,2 \%. Em relação ao Valor Preditivo Negativo (VPN \%), que avalia probabilidade de não ocorrência da doença quando o resultado do ensaio é negativo, obtivemos 98,8 \%, enquanto Aita e colaboradores (2013) e os fornecidos pelo fabricante (INOVA) foram respectivamente de $96,4 \%$ e $97,2 \%$.

Analisando os VPPs encontados com os de Aita e colaboradores (2013) e os fornecidos pelo fabricante (INOVA), observamos que os dados do estudo são muito inferiores comparados aos outros dados da literatura, considerando que o VPP avalia a chance de ocorrência de DC quando um resultado de tTTG IgA for positivo, é passível afirmarmos que o valor obtido em nosso estudo de $69,2 \%$, seja realmente próximo ao encontrado na prática laboratorial, uma vez que outros autores já afirmaram a ocorrência de resultados falso positivos de tTG IgA em pacientes com outras doenças como: doença crônica do fígado, linfoma, giardíase e doenças reumatológicas (BIZZARO et al., 1999; CARROCCIO et al., 2002; SORELL et al., 2002; PICARELLI et al., 2003). Já para o VPN os valores encontrados em nosso estudo foram maiores que os do estudo encontrado na literatura e os dados do fabricante, o que coloca nosso dado como verdadeiro negativo, com um percentual baixo de erro.

Quando analisamos a Razão de Verossimilhança Positiva (RVP \%) obtivemos 27, enquanto Aita e colaboradores (2013) e os fabricante (INOVA) obtiveram 31,9 e 35,5, respectivamente. Considerando que quanto maior for a RVP melhor é a sua capacidade em distinguir resultados positivos de negativos, e melhor seu desempenho analítico, nosso resultado embora inferior ao já descritos pelo estudo anterior e pelo fabricante, ainda assim apresenta um excelente desempenho.

O mesmo ocorreu para a Razão de Verossimilhança Negativa (RVN \%), quando obtivemos 0,19, enquanto Aita e colaboradores (2013) e o fabricante (INOVA) obtiveram 0,04 e 0,0 , respectivamente. Colocando a possibilidade de a RVN refletir a capacidade do método de diferenciar indivíduos negativos e positivos, e sabendo que quanto mais próximo de zero maior é essa capacidade, consideramos que o nosso valor seja compatível com os demais dados do nosso estudo, entretanto não podemos deixar de ressaltar que o dado fornecido pelo fabricante é passível de ser questionado, uma vez que em qualquer dosagem 
analítica laboratorial há erros inerentes a fase analítica que são contabilizados e valores absolutos como estes são pouco prováveis de serem encontrados.

Em relação ao Risco Relativo (RR) 58,5 (IC 95\% 14,07 a 243,2) vezes e o Odds Ratio (OR) de 187,9 (IC 95\% 30,27 a 1166) vezes, não foi possível estabelecer comparações com a literatura, uma vez que refletem a probabilidade e a chance de desenvolvimento da DC de acordo com os resultados encontrados neste estudo.

Por fim, realizamos a comparação entre os métodos de ELISA e quimioluminescência por meio da curva ROC, que foi realizada com o intuito de avaliar o desempenho no que diz respeito a exatidão e precisão de ambos os ensaios, individualmente. Os resultados obtidos revelam ótima acurácia, já que a área sob a curva foi de 0,9972, e estudos realizados por Lakos e colaboradores (2014) e Aita e colaboradores (2013), obtiveram exatidão de 0,97. 


\section{CONCLUSÃO}

Neste trabalho, estudamos a performance analítica dos anticorpos antitransglutaminase $\operatorname{IgA}$ utilizando a quimioluminescência como método laboratorial para diagnosticar doença celíaca. $\mathrm{O}$ índice Kappa revelou substancial concordância $(\mathrm{k}=0,732)$, os CVs para controles negativos de 4,4\% e 2,9\% e para controles positivos de 3,4\% e 2,7\%, demonstram alta exatidão na precisão intraensaio e alta exatidão na precisão interensaio, respectivamente. O método apresentou sensibilidade de $81,8 \%$, especificidade de $97,6 \%$, e acurácia de 94\%, mostrando-se mais sensível que específico quando comparado ao método referência.

No que se refere ao desempenho clínico-laboratorial, o método demonstrou Valor Preditivo Positivo (VPP) de 69,2\% e Valor Preditivo Negativo (VPN) de 98,8\%, que comprova elevada capacidade de discriminar indivíduos celíacos e não-celíacos, somada a curva ROC, que apresentou área sobre a curva de 0,9972. Quanto ao Risco Relativo quando a anti-tTG IgA apresentar resultado positivo, foi observado índice de 58,5 (IC 95\% 14,07 a 243,2) vezes maior para o desenvolvimento de DC, além do Odds Ratio de 187,9 (IC 95\% 30,27 a 1166) o que demonstra forte associação entre o exame positivo e a chance de desenvolver DC.

É possível concluir que a metodologia de quimioluminescência possui capacidade de discriminar indivíduos celíacos de não celíacos, podendo ser utilizada como método para diagnóstico laboratorial da doença celíaca. 


\section{REFERÊNCIAS}

ABADIE, $\mathrm{V}$. et al. Integration of genetic and immunological insights into a model of celiac disease pathogenesis. Annu Rev Immunol, v. 29, p. 493-525, 2011

AGA INSTITUTE. AGA institute medical position statement on the diagnosis and management of celiac disease. Gastroenterology, v. 131, p. 1977-1980, 2006.

AITA, A. et al. Chemiluminescence and ELISA-based serum assays for diagnosing and monitoring celiac disease in children: a comparative study. Clin Chim Acta, v. 421, p. 202-7, Jun 52013.

BAEYENS, W. R. et al. Chemiluminescence-based detection: principles and analytical applications in flowing streams and in immunoassays. J Pharm Biomed Anal, v. 17, n. 6-7, p. 941-53, Sep 11998.

BAO, F.; GREEN, P. H.; BHAGAT, G. An update on celiac disease histopathology and the road ahead. Arch Pathol Lab Med, v. 136, n. 7, p. 735-45, Jul 2012

BARDELLA, M. T. et al. Serological markers for coeliac disease: is it time to change? Dig Liver Dis, v. 33, n. 5, p. 426-31, Jun-Jul 2001.

BASSO, D. et al. A new indirect chemiluminescent immunoassay to measure anti-tissue transglutaminase antibodies. J Pediatr Gastroenterol Nutr, v. 43, n. 5, p. 613-8, Nov 2006.

BIZZARO, N.; PASINI, P.; FINCO, B. False-positive reactions for IgA anti-phospholipid and anti-beta(2)-glycoprotein I antibodies in patients with IgA monoclonal gammopathy. Clin Chem, v. 45, n. 11, p. 2007-10, Nov 1999.

BRANDTZAEG, P. Mucosal immunity: induction, dissemination, and effector functions. Scand J Immunol, v. 70, n. 6, p. 505-15, Dec 2009.

CAJA, S. et al. Antibodies in celiac disease: implications beyond diagnostics. Cellular \& Molecular Immunology, v. 8, p. 103-109, 2011.

CARROCCIO, A. et al. Comparison of anti-transglutaminase ELISAs and an antiendomysial antibody assay in the diagnosis of celiac disease: a prospective study. Clin Chem, v. 48, n. 9, p. 1546-50, Sep 2002.

CHANG, M.; GREEN, P. H. Genetic testing before serologic screening in relatives of patients with celiac disease as a cost containment method. J Clin Gastroenterol, v. 43, n. 1, p. 43-50, Jan 2009.

CHORZELSKI, T. P. et al. IgA anti-endomysium antibody. A new immunological marker of dermatitis herpetiformis and coeliac disease. Br J Dermatol, v. 111, n. 4, p. 395-402, Oct 1984. 
COLLIN, P. et al. Antiendomysial and antihuman recombinant tissue transglutaminase antibodies in the diagnosis of coeliac disease: a biopsy-proven European multicentre study. Eur J Gastroenterol Hepatol, v. 17, n. 1, p. 85-91, Jan 2005.

COMMISSION, I. O. F. S. I. E. International vacabulary of metrology - Basic and general concepts and associeted terms. Guide 99. Genebra 2007.

CROWTHER, J. R. Methods in Moleculary Biology. New Jersey: Humana Press, 1995.

DAHLBOM, I. et al. Immunoglobulin $\mathrm{G}$ ( $\mathrm{IgG}$ ) anti-tissue transglutaminase antibodies used as markers for IgA-deficient celiac disease patients. Clin Diagn Lab Immunol, v. 12, n. 2, p. 254-8, Feb 2005.

DEEKS, J. J. Using evaluations of diagnostic tests: understanding their limitations and making the most of available evidence. Ann Oncol, v. 10, n. 7, p. 761-8, Jul 1999.

DIAMANDIS, E. P.; CHRISTOPOULOS, T. K. Immunoassay. California: Academic Press, Inc., 1996.

DICKE, W. K.; WEIJERS, H. A.; VAN DE KAMER, J. H. Coeliac disease. II. The presence in wheat of a factor having a deleterious effect in cases of coeliac disease. Acta Paediatr, v. 42, n. 1, p. 34-42, Jan 1953.

DIETERICH, W. et al. Identification of tissue transglutaminase as the autoantigen of celiac disease. Nat Med, v. 3, n. 7, p. 797-801, Jul 1997.

DOWD, B.; WALKER-SMITH, J. Samuel Gee, Aretaeus, and the coeliac affection. Br Med J, v. 2, n. 5909, p. 45-7, Apr 61974.

FERREIRA, A. W.; MOARES, S. L. Diagnóstico Laboratorial das Principais Doenças Infecciosas e Autoimunes. 3. Rio de Janeiro: Ed. Guanabara Koogan, 2013.

FRULIO, G. et al. Evaluating diagnostic accuracy of anti-tissue Transglutaminase IgA antibodies as first screening for Celiac Disease in very young children. Clin Chim Acta, v. 446, p. 237-40, Jun 152015.

GIERSIEPEN, K. et al. Accuracy of Diagnostic Antibody Tests for Coeliac Disease in Children: Summary of an Evidence Report. Journal of Pediatric Gastroenterology and Nutrition, v. 54, p. 229-241, 2012.

GROSSMANN, K. et al. Simultaneous detection of celiac disease-specific IgA antibodies and total IgA. Auto Immun Highlights, v. 7, n. 1, p. 2, Dec 2016.

HILL, I. D. et al. Guideline for the diagnosis and treatment of celiac disease in children: recommendations of the North American Society for Pediatric Gastroenterology, Hepatology and Nutrition. J Pediatr Gastroenterol Nutr, v. 40, n. 1, p. 1-19, Jan 2005.

HILL, I. D. What are the sensitivity and specificity of serologic tests for celiac disease? Do sensitivity and specificity vary in different populations? Gastroenterology, v. 128, n. 4 Suppl 1, p. S25-32, Apr 2005. 
HILL, P. G. et al. IgA antibodies to human tissue transglutaminase: audit of routine practice confirms high diagnostic accuracy. Scand J Gastroenterol, v. 39, n. 11, p. 1078-82, Nov 2004

HOLLON, J. et al. Effect of gliadin on permeability of intestinal biopsy explants from celiac disease patients and patients with non-celiac gluten sensitivity. Nutrients, v. 7, n. 3, p. 1565 76, Mar 2015.

HUSBY, S. et al. European Society for Pediatric Gastroenterology, Hepatology, and Nutrition guidelines for the diagnosis of coeliac disease. J Pediatr Gastroenterol Nutr, v. 54, n. 1, p. 136-60, Jan 2012.

HUSBY, S.; MURRAY, J. Defining Thresholds of Antibody Levels Improves Diagnosis of Celiac Disease: Replacing the Gold Standard. Clinical Gastroenterology and Hepatology, v. 11, p. 404-405, 2013.

INSTITUTE, A. G. A. AGA Institute Medical Position Statement on the Diagnosis and Management of Celiac Disease. Gastroenterology, v. 131, n. 6, p. 1977-80, Dec 2006.

KELLY, C. P. et al. Advances in diagnosis and management of celiac disease. Gastroenterology, v. 148, n. 6, p. 1175-86, May 2015.

KHOSHBATEN, M. et al. Celiac disease and multiple sclerosis in the northwest of Iran. Bratisl Lek Listy, v. 113, n. 8, p. 495-7, 2012.

KONING, F. et al. Pathomechanisms in celiac disease. Best Pract Res Clin Gastroenterol, v. 19, n. 3, p. 373-87, Jun 2005.

LAKOS, G. et al. Analytical and clinical comparison of two fully automated immunoassay systems for the diagnosis of celiac disease. J Immunol Res, v. 2014, p. 371263, 2014.

LAVOISIER, A.; SCHLAEPPI, J. M. Early developability screen of therapeutic antibody candidates using Taylor dispersion analysis and UV area imaging detection. MAbs, v. 7, n. 1, p. 77-83, 2015.

LEFFLER, D. et al. Kinetics of the histological, serological and symptomatic responses to gluten challenge in adults with coeliac disease. Gut, v. 62, n. 7, p. 996-1004, Jul 2013.

LEFFLER, D. A.; SCHUPPAN, D. Update on serologic testing in celiac disease. Am J Gastroenterol, v. 105, n. 12, p. 2520-4, Dec 2010.

LEWIS, N. R.; SCOTT, B. B. Systematic review: the use of serology to exclude or diagnose coeliac disease (a comparison of the endomysial and tissue transglutaminase antibody tests). Aliment Pharmacol Ther, v. 24, n. 1, p. 47-54, Jul 12006.

LINDEN, A. Measuring diagnostic and predictive accuracy in disease management: an introduction to receiver operating characteristic (ROC) analysis. J Eval Clin Pract, v. 12, n. 2, p. 132-9, Apr 2006 
LINDFORS, K. et al. Galactosylation of serum IgA1 O-glycans in celiac disease. J Clin Immunol, v. 31, n. 1, p. 74-9, Feb 2011.

LIONETTI, E. et al. Celiac disease from a global perspective. Best Practice \& Research Clinical Gastroenterology, v. 29, p. 365-379, 2015.

LIONETTI, E.; CATASSI, C. New clues in celiac disease epidemiology, pathogenesis, clinical manifestations, and treatment. Int Rev Immunol, v. 30, n. 4, p. 219-31, Aug 2011.

LUDVIGSSON, J. F. et al. Diagnosis and management of adult coeliac disease: guidelines from the British Society of Gastroenterology. Gut, v. 63, n. 8, p. 1210-1228, 2014.

LUDVIGSSON, J. F. et al. The Oslo definitions for coeliac disease and related terms. Gut, v. 62, p. 43-52, 2013.

MAHLER, M. et al. Detection of autoantibodies using chemiluminescence technologies. Immunopharmacol Immunotoxicol, v. 38, n. 1, p. 14-20, Feb 2016.

MARSH, M. N. Gluten, major histocompatibility complex, and the small intestine. A molecular and immunobiologic approach to the spectrum of gluten sensitivity ('celiac sprue'). Gastroenterology, v. 102, n. 1, p. 330-54, Jan 1992.

METZ, C. E. Basic principles of ROC analysis. Semin Nucl Med, v. 8, n. 4, p. 283-98, Oct 1978.

METZ, C. E. ROC analysis in medical imaging: a tutorial review of the literature. Radiol Phys Technol, v. 1, n. 1, p. 2-12, Jan 2008.

METZ, C. E.; HERMAN, B. A.; ROE, C. A. Statistical comparison of two ROC-curve estimates obtained from partially-paired datasets. Med Decis Making, v. 18, n. 1, p. 110-21, Jan-Mar 1998.

MONZANI, A. et al. Use of deamidated gliadin peptide antibodies to monitor diet compliance in childhood celiac disease. J Pediatr Gastroenterol Nutr, v. 53, n. 1, p. 55-60, Jul 2011.

MOZO, L. et al. Diagnostic value of anti-deamidated gliadin peptide IgG antibodies for celiac disease in children and IgA-deficient patients. J Pediatr Gastroenterol Nutr, v. 55, n. 1, p. 50-5, Jul 2012.

MUNOZ-BERBEL, X. et al. Monolithically integrated biophotonic lab-on-a-chip for cell culture and simultaneous pH monitoring. Lab Chip, v. 13, n. 21, p. 4239-47, Nov 72013.

MURCH, S. Recent Advances in Celiac Disease. Indian J Pediatr, Jun 82016

OBERHUBER, G.; GRANDITSCH, G.; VOGELSANG, H. The histopathology of coeliac disease: time for a standardized report scheme for pathologists. Eur J Gastroenterol Hepatol, v. 11, n. 10, p. 1185-94, Oct 1999 
O'FARRELLY, C. et al. Alpha gliadin antibody levels: a serological test for coeliac disease. Br Med J (Clin Res Ed), v. 286, n. 6383, p. 2007-10, Jun 251983.

PAULLEY, J. W. Observation on the aetiology of idiopathic steatorrhoea; jejunal and lymphnode biopsies. Br Med J, v. 2, n. 4900, p. 1318-21, Dec 41954.

PICARELLI, A. et al. Anti-tissue transglutaminase antibodies in arthritic patients: a diseasespecific finding? Clin Chem, v. 49, n. 12, p. 2091-4, Dec 2003.

RESS, K. et al. Use of a fully automated immunoassay for celiac disease screening in a pediatric population. Clin Chem Lab Med, v. 49, n. 6, p. 983-7, Jun 2011

ROSTAMI, K. et al. Sensitivity of antiendomysium and antigliadin antibodies in untreated celiac disease: disappointing in clinical practice. Am J Gastroenterol, v. 94, n. 4, p. 888-94, Apr 1999.

ROSTOM, A. et al. The diagnostic accuracy of serologic tests for celiac disease: a systematic review. Gastroenterology, v. 128, n. 4 Suppl 1, p. S38-46, Apr 2005.

ROSTOM, A.; MURRAY, J. A.; KAGNOFF, M. F. American Gastroenterological Association (AGA) Institute technical review on the diagnosis and management of celiac disease. Gastroenterology, v. 131, n. 6, p. 1981-2002, Dec 2006.

SAPONE, A. et al. Divergence of gut permeability and mucosal immune gene expression in two gluten-associated conditions: celiac disease and gluten sensitivity. BMC Med, v. 9, p. 23, 2011.

SCHUPPAN, D.; JUNKER, Y.; BARISANI, D. Celiac disease: from pathogenesis to novel therapies. Gastroenterology, v. 137, n. 6, p. 1912-33, Dec 2009.

SCHUPPAN, D.; ZIMMER, K. P. The diagnosis and treatment of celiac disease. Dtsch Arztebl Int, v. 110, n. 49, p. 835-46, Dec 62013.

SORELL, L. et al. Celiac disease diagnosis in patients with giardiasis: high value of antitransglutaminase antibodies. Am J Gastroenterol, v. 99, n. 7, p. 1330-2, Jul 2004.

SORELL, L. et al. One-step immunochromatographic assay for screening of coeliac disease. Lancet, v. 359, n. 9310, p. 945-6, Mar 162002.

STAMNAES, J.; SOLLID, L. M. Celiac disease: Autoimmunity in response to food antigen. Semin Immunol, v. 27, n. 5, p. 343-52, Sep 2015

SULKANEN, S. et al. Tissue transglutaminase autoantibody enzyme-linked immunosorbent assay in detecting celiac disease. Gastroenterology, v. 115, n. 6, p. 1322-8, Dec 1998.

TAYLOR, K. B. et al. An immunological study of coeliac disease and idiopathic steatorrhoea. Serological reactions to gluten and milk proteins. Br Med J, v. 2, n. 5269, p. 1727-31, Dec 301961. 
TONUTTI, E. et al. Diagnostic efficacy of the ELISA test for the detection of deamidated anti-gliadin peptide antibodies in the diagnosis and monitoring of celiac disease. J Clin Lab Anal, v. 23, n. 3, p. 165-71, 2009.

TONUTTI, E.; BIZZARO, N. Diagnosis and classification of celiac disease and gluten sensitivity. Autoimmun Rev, v. 13, n. 4-5, p. 472-6, Apr-May 2014.

TRYNCA G, et al. Dense genotyping identifies and localizes multiple common and rare variant association signals in celiac disease. Nature genetics.; v. 43(12), p. 1193-1201, Nov 2011

UTIYAMA, S. R. R. et al. Correlation of anti-endomysial and antitransglutaminase antibodies with celiac disease. Revista Brasileira de Análises Clínicas, v. 34(1), p. 39-45, 2002.

VAZ, A. J.; TAKEI, K.; BUENO, E. C. Imunoensaios: fundamentos e aplicações. Rio de Janeiro: Guanabara Koogan, 2007.

VERMEERSCH, P. et al. Serological diagnosis of celiac disease: comparative analysis of different strategies. Clin Chim Acta, v. 413, n. 21-22, p. 1761-7, Nov 122012.

VIVES-PI, M. et al. Biomarkers for diagnosis and monitoring of celiac disease. J Clin Gastroenterol, v. 47, n. 4, p. 308-13, Apr 2013.

WALLACH, J. B. Interpretação de Exames Laboratoriais. Rio de Janeiro: Ed Guanabara Koogan, 2013.

WOLTERS, V. M.; WIJMENGA, C. Genetic background of celiac disease and its clinical implications. Am J Gastroenterol, v. 103, n. 1, p. 190-5, Jan 2008.

ZHANG, H. et al. Biomarkers for monitoring pre-analytical quality variation of mRNA in blood samples. PLoS One, v. 9, n. 11, p. e111644, 2014.

ZINTZARAS, E.; GERMENIS, A. E. Performance of antibodies against tissue transglutaminase for the diagnosis of celiac disease: meta-analysis. Clin Vaccine Immunol, v. 13, n. 2, p. 187-92, Feb 2006 


\section{ANEXO}

Plotoforma MiviBTERIO DA SAODE - Conseino Nacional de Saude - Comisabo Nacional de Etica em Pesquisa - CONEP

Grarill PROJETO de PEsquisa ENVOLVENDO seres humanos

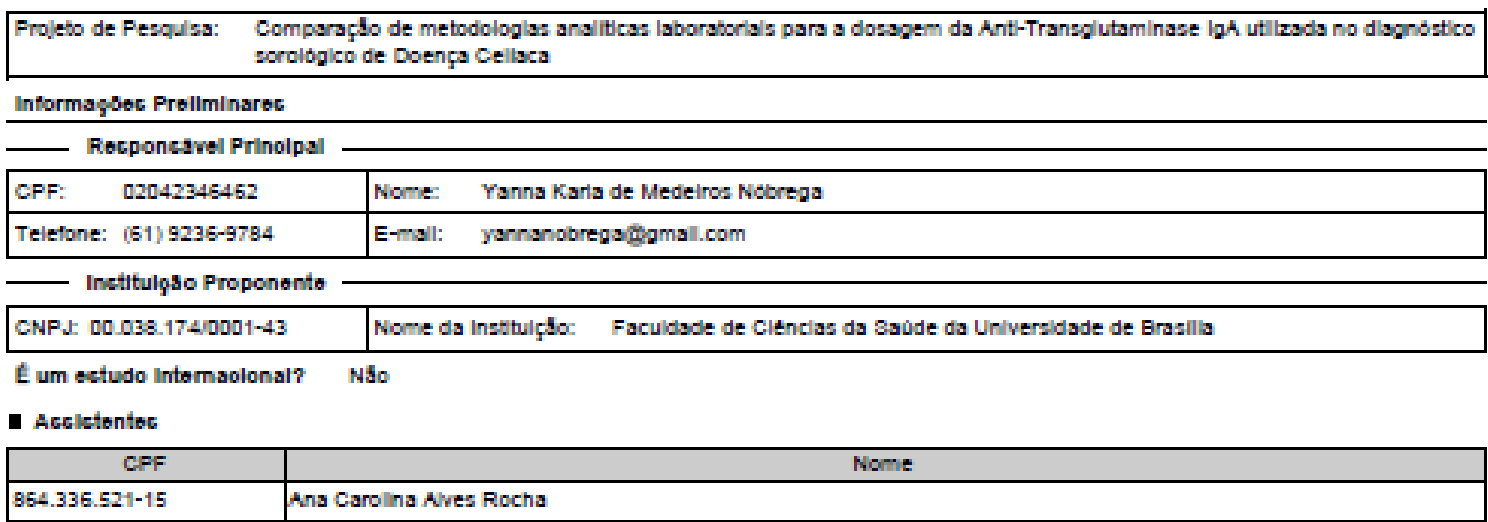

Area de Ectudo

Orandec Areac do Conheolmento (CNPq)

- Grande Area 4. Clencias da saúde

Propocito Prinolpal do Ectudo (OMs)

+ Outroe

Titulo Publloo da Pecquica: Comparş̧⿸丆口 de metodologlas analiticas laboratorials para a dossgem da Ant-Tranaglutaminase lgA uflizada no dlagnoatico sorologico de Doença Cellaca

Contato Publloo

\begin{tabular}{|c|l|l|l|}
\hline CPF & \multicolumn{1}{|c|}{ Nome } & Teiefone & E-mall \\
\hline 02042346462 & Yanna Karia de Medeiroa Nobrega & (61) 9236-9784 & yannanobregagamal.com \\
\hline
\end{tabular}

Contato Yanna Karia de Medeiroa Nobrega 
Docenho:

Comparaçblo de metodologlas analiticas laboratorials para a doasgem da Ant-Tranaglutaminase loA uflizada no dagndatico sorologico de Doença Cellaca, avalisndo a senalbildade e especincidade da mebodologla de quimloluminesctncia a ser teatada com o padiffo-ouro que e a metodologla de ELIOA

Apolo Finanooiro

\begin{tabular}{|c|c|c|c|c|}
\hline CNPJ & Nome & E-mal & Telefone & Tipo \\
\hline & & & & $\begin{array}{l}\text { Financiamento } \\
\text { Proprio }\end{array}$ \\
\hline
\end{tabular}

Palavra Chavo

Palavra-chave

Quim/olumineactencia, ELISA, anti-transglutaminase lgA, validaçdo, doença cellaca

Detalhamento do Ectudo

Rocumo:

A doença celisca (CD) e uma enteropatia suto-imune medlada, provocada por uma intolerdncis permanente ao gluten em individuos susceptiveis (GABGARRINI et al., 2008, GREEN a CELIER, 2007). Estudos de prevalencia da DC tem demonstrado que ela e mala frequente do que se pensavs,

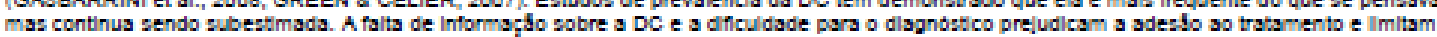
as possbilldades de meihora do quadro clinico. Fesqulasa revelam que a doença atinge pessoss de todas as ldades, mas compromete principaimente crianças de 6 meses as 5 anos de idade. Fol tambem observada frequencla malor em pacientes do sexo feminino, na proporç duas mulheres para cads homem. O carater hereditario da doença boma imprescindivel que parentes em primeiro gras de celiscos se submetam ao teste para sus detecç0 (FABANO \& CATABS1, 2001; FABANO ET AL., 2003; PRATEBI ET AL., 2003). De acordo com o ultimo relatorio de

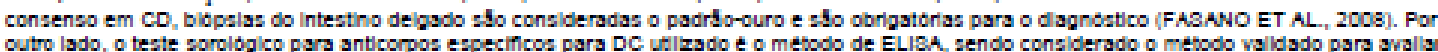
outro lado, o teste sorolopico para anticorpos especificoa para DC ülizado e o mebodo de ELIBA, sendo considerado o metodo validado para avaliar paciente cellaco, como por exemplo, tranggressio a dieta (BRABIL, 2009). Considerando a importancla da DC e susa poselbilldades atuals de tratamento, o desenvolvimento de pesquisas que insiram novas atemativas dlagnostcas no ambio laboratorial pode apresentar resultados importantes, aumentando eapecifcidsde e senalbilidade e diminuindo o custo dos erames, alem de minimizar a necessidade da realizaç5́o de exames invasivoa, que exigem grande hablldade tecnica. Dessa forma ensalos recombinantes de quimiluminesctncis tTG-igA humano foram dezenvolvidos e podem ser dosados em anslaadores de imunoensalos (IMMULITE 20006, alemenas. Alemanhs e Eloflash, Werten Medicals, Eapanha). Erass platatormas permitem teates em grande eacala com eievado rendimento, ums vantapem que deve ger levoda em conta devido as creacente aumento na solicitaçso e execuçajo de testes sorologicos que detectam a doença.

Introdugsa:

A doença celisca (DC) e uma enteropatia imuno-mediada caracterizada por inflamaç̧o cronica do inteatino deigado, que acomete indlviduoa peneticamente auscetivels. $O$ tator desencadeante da doença e a ingestílo de gluten, um complexo proteico encontrado em cereala como tripo. cevada e centelo. O deservolvimento da DC e consequente a combinaçio desses fabores geneticos e ambientais que podem redundar em variavel

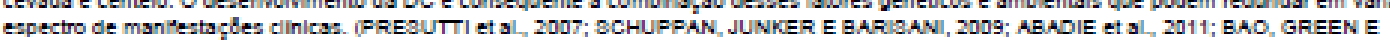
eapectro de manifeataçdes clinicas. (PREQUTTI et al., 2007; OCHUPFAN, JUNKER E GARIBANI, 2009; ABADIE et al, 2011; BAO, GREEN E bomando uma das mals comuns no mundo. Estudos epidemlologicos na Europa e nos Estados Unidos, moatram uma prevalencia de $1 \%$ da DC na

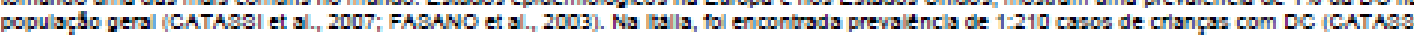
et al., 1996). Em Portugal a prevaiencia encontrada, em adoleacentes na populaçbo geral, fol de 1:134 (ANTUNES et al, 2006). Na Tuniala, a prevalencla fol 1:157 crianças com DC (HARZ et al, 2007). No Brasl estudos realizados em diferentes regilez moetraram uma prevalencla para DC variando entre 1:214 e 1:417 em adultos e 1:184 em crianças (CROVELLA et al, 2007; PEREIRA et al, 2006; MELO et al, 20D5; PRATESI et al)

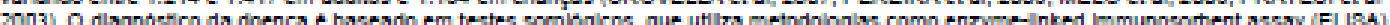
Imunofuorescencis indireta para detectar a presença de anticonos ant-traneglutamingse e art-endomis/o, respectivamente (ABADIE et al, 2011). Imunofuorescencis indireta para detectar a presença de anticonos ant-transg utam insae e anti-endomislo, respectivamente (ABADIE et al, 2011) Para confirmaça do disgnostico pode ser requerida blopsia integtinal do paciente, onde s\$o observadas anomalas como hiperplas a da cripta e senalvela e eapecifcos, de facll execuçso, e ha uma vasta gama de kits comerciala disponivela. O teate de imunogiobulina $\mathrm{A}$ (lo A) contra o antigeno de tecido de trangolutaminase (TTG) e aceito como a me hor ferramenta de rastreio para DC, e ate pouco tempo ao poderis ser realizado utilzando a metodologia de ELIBA (FABANO ET AL., 2008). Recentemente, um novo enasio TTG -loA humano fol lançado peia metodologla de

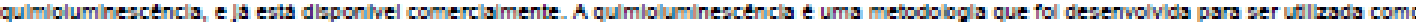
mitodo atemativo aps radioigotopos nos imunoenasios. Erse fenomeno pode ser definido de uma maneira simples como reaçles quimlcas que emitem luz. Esasa reaçles se dfo peis transiçblo de eietrona a partir de seu eatado fundamental para um eatado eietrónico animado, acompanhado

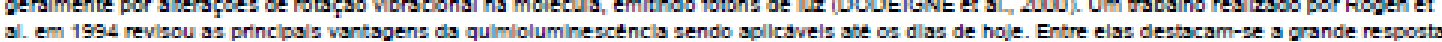
a. em 1994 revisou as principals vantapens da quimioluminesctncla sendo aplicavels ast oa dlas de hoje. Entre elas destacam-ge a grande respost a

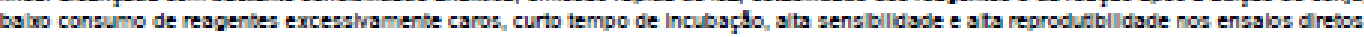
Indiretos, competitivos e imunometricos, alem de asaencia de tovicidade. Comerciaimente foram lançados dola kita que utilizam a metodologia de quimiolumineactencia, um fabricado pela alemengb (Eriangen, Alemanha) para uso com o analeador IMMUULITE 20006 e outro fabricado pela Werfen Medicab (Barcelons, Espanha) para 0 analigador Blo-Flashs. Estes kits embora eatejam sendo utlizados comercisimente em alguna

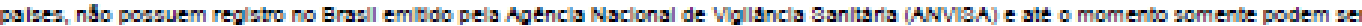
utlizadoa pars pezousa, o que representa uma exceiente oportunidade para comparaç5o entre metodologlsa, uma vez que o padrlo-ouro utllzado e

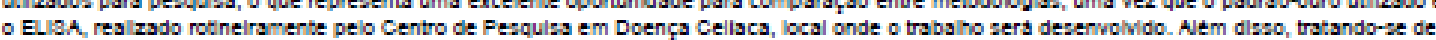
o ELiaA, realzado rotneiramente peio Centro de Peaquisa em Doença Celisca, local onde o trabaino sers dezenvolvido. Alem dlszo, tratando-se de grande escala com eievodo rendimento, uma vantagem que deve ser ievada em conta devido as crescentes solicitaçbes medicas de exames e a utlizaçso de testes de sorologls. Os sistemas automatizadoa quimioluminescentes em sua grande maloria sto randomizados, permitem malor

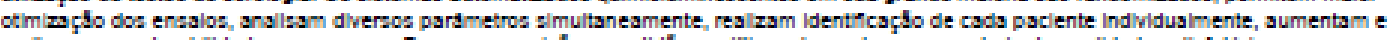
meinoram a rastreabildade e segurança. Possuem preclabo e exatidso analitica adequadoa para controle de quallisde sassfatorio, com senabiliade e eapecificidade compativeia com outroa metodoa padrfo-ouro, alem de robuatez, praficidade e rapidez na lberaçio dos resultadoa. 
Comparar metodologlas ansilticas comparando com a metodologla padrío-ouro

Objotivo Primarlo:

Comparar duas metodologlas utlzadas para a doasgem de anti-tranaglutaminase loA (AnthitTG lgA).

Objetivo sooundario:

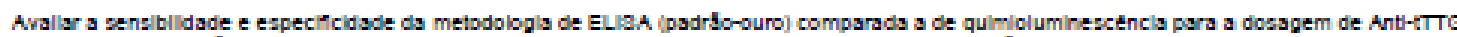

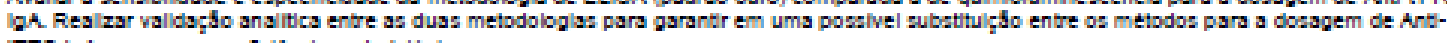
ITTG IgA, segurança e eficlencla metodologicas.

Motodologla Propocta:

4.1. Obtençlo do material blologico As amostras utllzadas serdo fomecidas da soroteca do Centro de Pesquisa em Doença Cellaca (CrOC), sendo provenientes de pacientes acompanhados no ambulatorio de Doença Cellaca do Hoaplial Universitario de Braslla (HUa), que se submeteram a participar de estudos realzados peio referido laborabbrio anterionmente. Aa amoatras eatSo armazenadas a - 20"C, e serfo descongeladas para

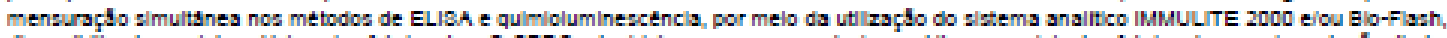

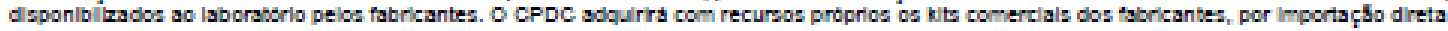
atravts da Icença pesquisador para serem usados apenas na pesqules. 4.2. Principlo dos procedimentos - Antl-1TG IgA, IMMUUITE 2000, Siemens: e um ensalo de fase solda, sequencial quimlolumineacente. A fase solids, uma perola de polleatreno e recoberta com um antipeno de trangolutaminsae tisaular (tTG). A amoatra do paciente e a perola recoberta sto adicionadas ao Tubo de Reaçlo. Uma fosfatase aicalina marcads

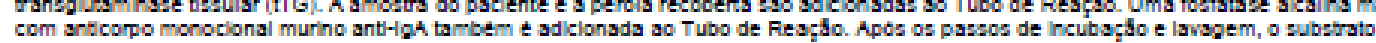
quimioluminescente (dloxetano) val hidrollas na presença de fostatase alcaina (marcador dos enasalos). A Anti-tranaglutaminase lgA e um ensalo

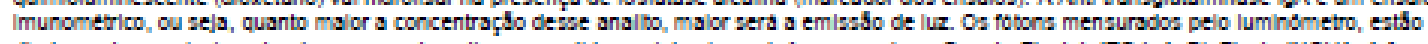
diretamente correlacionados a presença de anticorpos anti-tranaglutaminase lgA na amostra. - Quanta Flash h-tTG IgA, BloFlash, NOVA: A fase sollda desae ensalo e composta por h-fTG recomb inante reveatido em ezteras de latex paramagneticas, que eatSo no cartucho de reagentea, que conserva o antigeno em seu eatado reativo. Ao utlizar o reagente pela primeira vez, uma zoluçjo tamponada e adicionada as tubo que contem as eaferas paramagnetcas e em segulda, o cartucho de reagente e inserido no instrumento EloFlash. No equipamento, as amoatras afo previamente

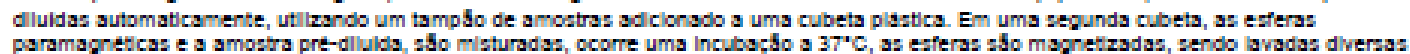
vezes. Apos as lavspena e adiclonsdo o leoluminol e incubs-se mals uma vez. Respentes atvadores se conlugam com o lsoluminol, provocando a reaç5o luminescente, sendo por sua vez medida peio luminometro do equipamento. A quantidade de luz emitida, e proporclonal a quantidade de ant -tranaglutaminase loA presente na amoatra do paciente. - Cuanta Libe R h-tTG laA, ELIBA, INONA (PADRAO-OURO): Poços da microplaca sto revestidos com antipeno tTG recombinante. As amostras sfo plpetadas nos poços, os autoanticorpos que reconhecem o antigeno tTG llgam-se durante a primeira incubaç5o. Apos a lyvagem dos poços, para remoç5o de anticorpos presentes nas amostras do paciente que nílo se llgaram, e adicionado o conjugado de cabra antiligA marcado com peroxidase purficado. O conlugado llga-se ao anticomo humano capturado e 0 excesso de conjugado e removido por lyvagens. Apos a adlçbo do subatrato TMB forma-se um produto de cor azul, cula intensidade e proporelonsl a

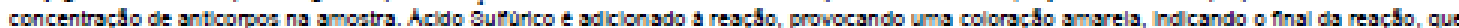

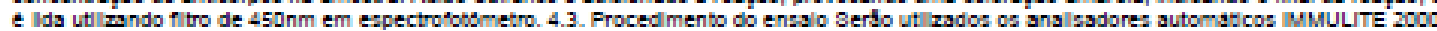
elou Blofisah como metodoa quimioluminescentes. Todos oa procedimentos de manutençlo de rotina, conforme recomendado pelos fabricantes.

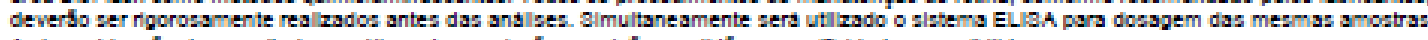

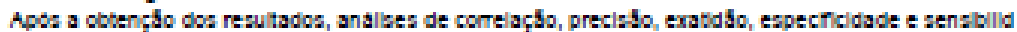

Ricooc:

NSo ha riscos diretos ace pacientes envolvidos no projeto

Benefloloc:

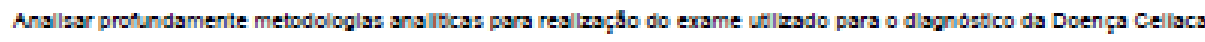
Motodologla de Anallce de Dadoc:

4.10. Ansilse eztaslatica Apos as dosspens realizadas nos dols slatemas analiticos, serfo analladas as performances dos slatemas

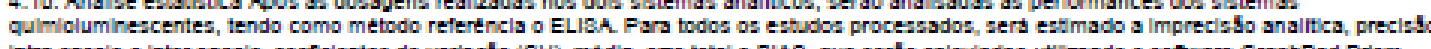
Intra ensalo e inter enas/o, coeficlentes de varisçio (CV), medla, emo botal e elas, que serdo caiculadas utllizando o software GraphPad Priam

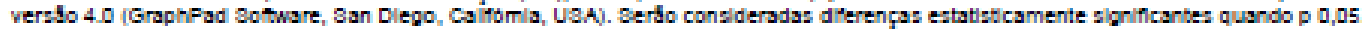

Decteoho Primario:

Valldar e comparar as metodologlas testadas

Tamanho da Amoctra no Bracll: 300

Paicec de Reorutamento

\begin{tabular}{|c|l|c|}
\hline Pals de Oripem do Estudo & \multicolumn{1}{|c|}{ Pals } & No de particlpantes da pesquias \\
\hline aim & ERABIL & 300 \\
\hline
\end{tabular}


Outrac Informsģoec

Havera ueo de fontec ceoundarlac de dadoe (prontuarioc, dadoc demograflooc, eto)?

aim

Dotalhamento:

Amoatra coletadas de projetos anteriores, culo procedimento de coleta de amostra tem um termo adtivo asainado peio paciente.

Informe o nemero de Indlviduec aberdadoc peccosimente, reorutadoc, ou que cotrerse algum tipe de intervengso necto oentro de pecquica:

300

Grupec em que cerso dlvidldoc oc partiolpantec da pecqulca necte oentro

\begin{tabular}{|l|l|l|}
\hline \multicolumn{1}{|c|}{ ID Grupo } & $\mathrm{N}^{2}$ de Indlviduos & \multicolumn{1}{c|}{ Intervençdes a serem relzadas } \\
\hline Cellocos dlagnosticados & 200 & tTTG IgA \\
\hline Controles nSo cellacos & 100 & tTTG IgA \\
\hline
\end{tabular}

O Ectudo o Multiodntrioo no Bracil?

N50

Propse dlepenca do TCLE?

Sim

Juctinloativa:

Facientes ja sasinaram termo adrvvo de coleta de sangue para utllzaçlo de amostras em outras pesquisas.

Havera retenģso de amoctrac para armazenamento em banoo?

N5o

Cronograma de Exeougsa

\begin{tabular}{|c|c|c|}
\hline Identificaçso da Etaps & InIClO (DDMMM/AMA) & Termino (DDMMMIAMMA) \\
\hline $\begin{array}{l}\text { 1- Submisabo ao Comise de Étrca em Pesquisas da } \\
\text { Faculdade de Clenclas da sadde (CEP/FB) }\end{array}$ & $29 / 11 / 2013$ & $31 / 01 / 2014$ \\
\hline 2- Levantamento de dados blbllograficoa & $29 / 11 / 2013$ & $28 / 02 / 2014$ \\
\hline $\begin{array}{l}\text { 3- Seleç̧o das amoatras biologicas ja obtidsa para } \\
\text { inclus } 50 \text { no trabalho }\end{array}$ & $03 / 03 / 2014$ & $30 / 05 / 2014$ \\
\hline $\begin{array}{l}\text { 4-Vallds;jo e aprendlzagem dos metodos e } \\
\text { tecnicas adotadas }\end{array}$ & $30 / 05 / 2014$ & $30 / 06 / 2014$ \\
\hline Dosagem das amostras teste & $02 / 06 / 2014$ & $29 / 08 / 2014$ \\
\hline 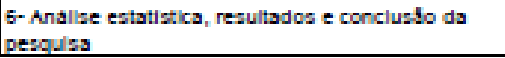 & $01 / 09 / 2014$ & $22 / 2 / 2014$ \\
\hline
\end{tabular}

Orģamento Finanoelro

\begin{tabular}{|c|c|c|}
\hline Identificaça de Orçamento & Tipo & Valor em Reala (R\$) \\
\hline $\begin{array}{l}\text { Recursos proprios para squalę̧lo de kits, soluçbes } \\
\text { elou aceseorio }\end{array}$ & Custelo & R5 $10,000,00$ \\
\hline
\end{tabular}

Total em R.5

F\$ 10000,00

Blbllograna:

ABADIE V et a:. Integration of Genetic and Immunological Insights into a Model of Cellac Disease Pathogenesla. Annual Review Immunology; 29:493 $-525,2011$. AGARDH, D. Antibodies against synthetic deamidasted gladin peptides and tiasue tranaglutaminase for the ident? cation of childhood

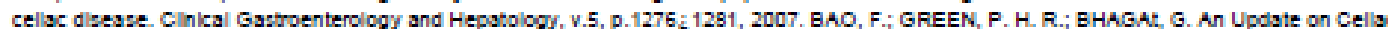
Celisc disesse. Cinical Gastroenterology and Hepastology, V.5, D.1276:1281, 2007. BAO, F.; GREEN, P. H. R.; BHAGMt, G. An Update on Cellse

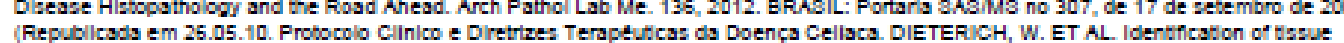

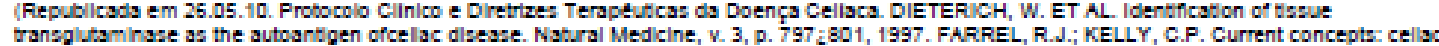

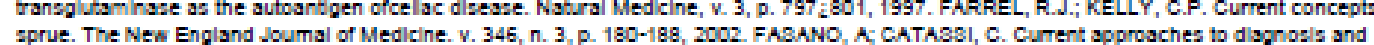
treatment of cellac dlsesse: an evolving spectrum; Gastroenterology; v. 120, D. 636-651, 2001. FABANO, A. ET AL. Prevalence of cellac disesse in at -risk an not-at-risk groups in the United atatea: a large multicenter study. Archives of Internal Medicine, v. 163, p. 296-292, 2003. FABANO, A. ET AL. Federation of intemational socieves of pedlatric gastroenterology, hepatology and nutrition conaenaus report on celac dlesease. Journal of Pedlaric Gastroenterology and Nutrition, v. 47, p. 214:219, 2008. GABQARRINI, G. ET AL. Cellac dlsease: whats new about ir? Dlgestive Diseases, v. 25, p. 121 127, 2008. GREEN, P. H., CELLIER, C. Cellac dlsesse. New England Joumal of Medicine, v. 357, D.1731; 1743, 2007. HiLL, 1.D. ET AL. North American society for Ped atric Gastroenterology, Hepstology and Nutrition. Guldeline for the dlagnosia and treatment of celac disease in chlldren:

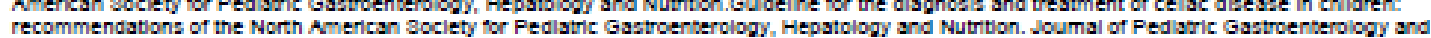
Nutrition, v. 40, p. 11-19, 2005. HUaBY, 3. Guideline - European Bociety for Fediatric Gastroenterology, Hepatology, and Nutriton Guldelines for the Disgnosis of Coeliac Disease. JPGN; $54: 136 ; 150,2012$. PRATEQI, et al. L. Frevaience of coelac disease: unexplained age-reiated variation in the same population. Scandingvian Joumal of Gastroenterology. v. 38, p. 747-50, 2003. PRESUTT, R. J. et a. Review - Celac Disesae. Am Fam Fhysiclan; 76:1795-1802, 2007. PRINCE, H. E. Evaiuston of the INOVA dlagnostics enzyme-linked immunosorbent assay kita for messuring serum Immunoglobulin $G(\mathrm{lg} G)$ and IgA to deamidated gladin peptides. Clinical and Vaccine Immunology, v.13, p. 150; 151, 2005. R.A3HTAK, a. ET AL. Comparatveusefuiness of deamidated glisdin antbodles in the dlagnosla of cellac dlsease. Cilnical Gastroenterology and Hepabology, v. 6, p. 426 : 432 , 2008. ROBTAMI, K. ET AL 
Qenaitivity of antiendomysium and antigladin antbodies in untreated celiac desese: disappointing in clinical practice. American Joumal of Gastroenterology, v. 94, D. 888-894, 2005. OCHUPPAN, D; JUNKER, Y. and BARISANI, D. Celac Dlsease From Pathogeneals to Novel Theraplez. Reviews in basic and clinical gastroenterology. Gastroenterology; 137:1912; 1933, 2009.

U Uplosd de Dooumentor

Arqulvo Anexoc?

\begin{tabular}{|c|c|}
\hline Tipo & Arqulvo \\
\hline Folha de Roato & Folha de Roato assingdapdf \\
\hline Outros & Carta para encaminhamento de projeto so CEP.pdr \\
\hline Outros & TERMO DE RESPONBABILIDADE E COMPROMISBO DO pEsquisador.pdr \\
\hline Outros & cep mod dlapenas TCLE.pdf \\
\hline Projeto Detalhado & Projeto final 01-12-13.doc \\
\hline
\end{tabular}

Finallzar

Manter alglo da integra do projeto de pesquias:

N5o 